\title{
Ozone profiles in the Baltimore-Washington region (2006-2011): satellite comparisons and DISCOVER-AQ observations
}

\author{
Anne M. Thompson • Ryan M. Stauffer • \\ Sonya K. Miller • Douglas K. Martins • Everette Joseph • \\ Andrew J. Weinheimer • Glenn S. Diskin
}

Received: 11 January 2013 /Accepted: 11 April 2014/

Published online: 14 May 2014

C) The Author(s) 2014. This article is published with open access at Springerlink.com

\begin{abstract}
Much progress has been made in creating satellite products for tracking the pollutants ozone and $\mathrm{NO}_{2}$ in the troposphere. Yet, in mid-latitude regions where meteorological interactions with pollutants are complex, accuracy can be difficult to achieve, largely due to persistent layering of some constituents. We characterize the layering of ozone soundings and related species measured from aircraft over two ground sites in suburban Washington, DC (Beltsville, MD, 39.05 N; 76.9 W) and Baltimore (Edgewood, MD, 39.4 N; 76.3 W) during
\end{abstract}

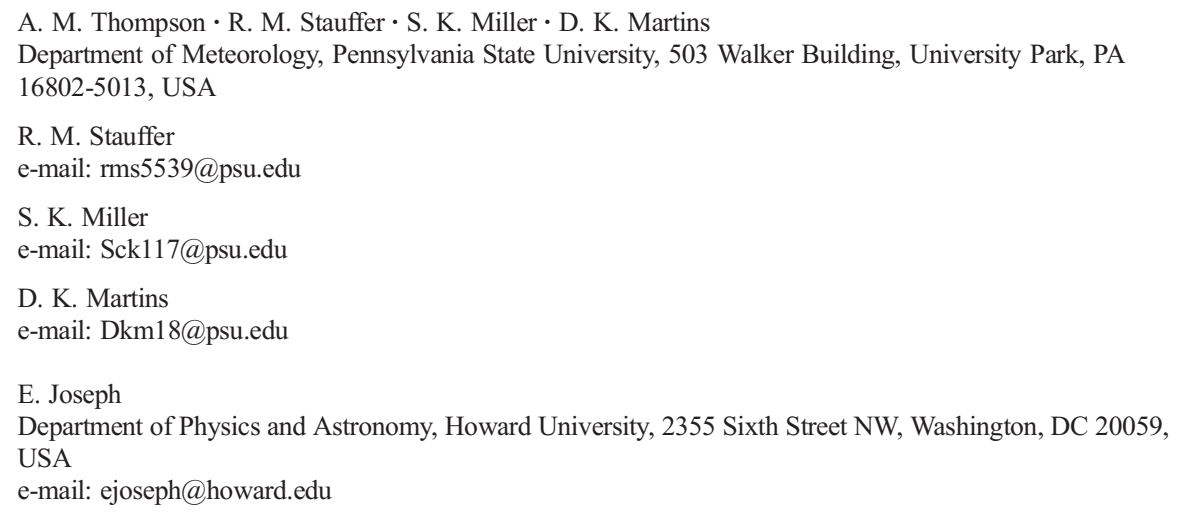

\section{A. J. Weinheimer}

Atmospheric Chemistry Division, NCAR, Boulder, CO 80307, USA

e-mail: wein@ucar.edu

G. S. Diskin

NASA Langley Research Center, MS 401B, Hampton, VA 23681, USA

e-mail: glenn.s.diskin@nasa.gov

Present Address:

A. M. Thompson $(\bowtie)$

NASA/Goddard Space Flight Center, Code 614, Greenbelt, MD 20771, USA

e-mail: anne.m.thompson@nasa.gov 
the July 2011 DISCOVER-AQ (Deriving Information on Surface Conditions from Column and Vertically Resolved Observations Relevant to Air Quality) experiment. First, we compare column-ozone amounts from the Beltsville and Edgewood sondes with data from overpassing satellites. Second, processes influencing ozone profile structure are analyzed using Laminar Identification and tracers: sonde water vapor, aircraft $\mathrm{CO}$ and $\mathrm{NO}_{\mathrm{y}}$. Third, Beltsville ozone profiles and meteorological influences in July 2011 are compared to those from the summers of 2006-2010. Sonde-satellite offsets in total ozone during July 2011 at Edgewood and Beltsville, compared to the Ozone Monitoring Instrument (OMI), were $3 \%$ mean absolute error, not statistically significant. The disagreement between an OMI/Microwave Limb Sounder-based tropospheric ozone column and the sonde averaged $10 \%$ at both sites, with the sonde usually greater than the satellite. Laminar Identification (LID), that distinguishes ozone segments influenced by convective and advective transport, reveals that on days when both stations launched ozonesondes, vertical mixing was stronger at Edgewood. Approximately half the lower free troposphere sonde profiles have very dry laminae, with coincident aircraft spirals displaying low CO (80-110 ppbv), suggesting stratospheric influence. Ozone budgets at Beltsville in July 2011, determined with LID, as well as standard meteorological indicators, resemble those of 4 of the previous 5 summers. The penetration of stratospheric air throughout the troposphere appears to be typical for summer conditions in the Baltimore-Washington region.

Keywords Tropospheric ozone $\cdot$ Stratosphere-troposphere exchange Satellite validation DISCOVER-AQ · Baltimore pollution · Ozonesondes · Washington DC pollution · Air quality · Carbon monoxide $\cdot$ Aircraft chemical measurements

\section{Introduction}

Although ground-level ozone is a routinely monitored pollutant in the US, important information about regional and intra- and inter-regional transport comes from measurements of ozone profiles because they encompass the levels in the middle and lower troposphere at which transport actually occurs. A multi-decadal record of ozone profiles taken by ozonesondes in the US exists for two sites only (Boulder, Colorado, $40 \mathrm{~N}, 105 \mathrm{~W}$; Wallops Island, Virginia, 37.85 N, 75.5 W). These records have been augmented since the 1990's at Huntsville, Alabama, typically not in the reach of an urban environment, and Trinidad Head, California, a station downwind of growing Asian emissions (Cooper et al. 2011). Since 2004 two urban regions have been sampled with some regularity during their ozone seasons: Houston, Texas, (Morris et al. 2006; Morris et al. 2010; Rappenglueck et al. 2008) and Washington, DC (Thompson et al. 2007a; Thompson et al. 2007b; Morris et al. 2007; Yorks et al. 2009). Influences on ozone include local pollution, long-range transport with occasional reaches from Canadian and Alaskan fires, and frequent enrichment by air of stratospheric origins. In the case of Washington, DC, these conclusions are consistent with summertime aircraft profiles over Maryland (Taubman et al. 2006; Hains et al. 2008).

A larger mid-Atlantic perspective on tropospheric ozone comes from Wallops Island (Newchurch et al. 2003; Normile et al. 2014, in review) and from the 2009 and 2010 CAPABLE (Chemistry and Physics of the Atmospheric Boundary Layer Experiment) soundings in Hampton, Virginia (37.1 N, 76.3 W). The latter observations are complemented by continuous surface ozone readings; the bay breeze effect from the adjacent Chesapeake Bay was isolated as an important component of ozone exceedance in the Hampton data (Martins et al. 2012). 
The 2011 DISCOVER-AQ (Deriving Information on Surface Conditions from Column and Vertically Resolved Observations Relevant to Air Quality) campaign put mid-Atlantic air quality (AQ) under a microscope, so to speak, during a polluted July, with ozone profiles measured by aircraft (NASA P-3, University of Maryland Cessna, NASA UC-12 with remote sensing instruments), frequent soundings in suburban Washington and Baltimore, and deployment of additional instrumentation at six EPA-certified monitoring sites maintained by the Maryland Department of Environment (MDE). The instruments, for which data at Edgewood and Beltsville, Maryland, are used in the present analysis, are listed in Table 1. They served a range of goals, from satellite validation, intercomparison of selected observations, flux determination, elucidation of boundary-layer structure over a diurnal cycle and the characterization of volatile organic compounds (VOC)- $\mathrm{NO}_{\mathrm{x}}$ relationships in an area with complex natural and anthropogenic sources of ozone precursors.

In this study we focus on ozone soundings taken during DISCOVER-AQ at the Beltsville, Maryland (39.05.N, 76.9 W) location, $20 \mathrm{~km}$ NE of downtown Washington, DC, and at Edgewood, Maryland (39.4 N; 76.3 W), $35 \mathrm{~km} \mathrm{NE}$ of downtown Baltimore. Surface ozone, $\mathrm{NO}_{\mathrm{y}}$ (reactive nitrogen consisting of $\mathrm{NO}+\mathrm{NO}_{2}+\mathrm{HNO}_{3}+\mathrm{PAN}+$ organic nitrates), $\mathrm{NO}$ and $\mathrm{CO}$ measurements were made continuously at both sites; selected VOC data are also available (Halliday et al. 2013). During P-3 flight days, fast ozone measurements were collected in aircraft spirals above Beltsville and Edgewood 3-4 times, with one or two of the spirals coinciding with the soundings. Detailed comparisons of $\mathrm{NO} / \mathrm{NO}_{2} /$ $\mathrm{NO}_{y}$ (Reed et al. 2013; Stauffer et al. 2012) and ozone (Martins et al. 2013) among ground-based, balloon-borne, aircraft instruments and satellites, where applicable, are presented in companion papers along with analysis of VOC composition at Beltsville (Doughty et al. 2012) and Edgewood (Halliday et al. 2013). This study addresses the following questions:

1. How do satellite-derived ozone column estimates compare to the Beltsville and Edgewood soundings? OMI total ozone and the OMI/MLS trajectory-enhanced tropospheric ozone residual (TTOR) products are evaluated.

Table 1 Instruments and data sets used

\begin{tabular}{|c|c|c|}
\hline Instrument/product & Data & Origin of data \\
\hline OMI & Total Column $\mathrm{O}_{3}, \mathrm{NO}_{2}$ & $\begin{array}{l}\text { Aura Satellite } \\
\text { http://avdc.gsfc.nasa.gov/index.php?site= } \\
\quad 666843934 \& \text { id }=13\end{array}$ \\
\hline TTOR & $\begin{array}{l}\text { Tropospheric Column } \mathrm{O}_{3} \\
\text { with GSFC trajectories } \\
\text { enhancing MLS \& OMI }\end{array}$ & ftp://hyperion.gsfc.nasa.gov/pub/aura/tropo3 \\
\hline $\begin{array}{l}\text { ECC Ozonesondes, } \\
\text { Radiosondes }\end{array}$ & Total, tropospheric Column $\mathrm{O}_{3}$ & $\begin{array}{l}\text { Edgewood, MD } \\
\text { Beltsville, MD }\end{array}$ \\
\hline Ozone analyzer & Continuous surface $\mathrm{O}_{3}$ & $\begin{array}{l}\text { Edgewood, MD (NATIVE Thermo 49c) } \\
\text { Beltsville, MD (MDE Thermo 49i) }\end{array}$ \\
\hline $\begin{array}{l}\text { NCAR Ozone-NO/NOy } \\
\text { Analyzer }\end{array}$ & $\begin{array}{l}\mathrm{NO}, \mathrm{NO}_{\mathrm{y}} \\
\text { Fast Response } \mathrm{O}_{3}\end{array}$ & $\begin{array}{l}\text { P-3 Spirals over Beltsville and Edgewood, MD } \\
\text { A J Weinheimer, PI }\end{array}$ \\
\hline $\begin{array}{l}\text { NASA/LaRC CO } \\
\text { DACOM }\end{array}$ & $\mathrm{CO}$ & $\begin{array}{l}\text { P-3 Spirals over Beltsville and Edgewood, MD } \\
\text { G S Diskin, PI; Sachse et al. } 1987\end{array}$ \\
\hline
\end{tabular}


2. What are the relative influences of processes like stratospheric intrusion and pollution transport on temporal ozone variability and vertical structure? This question is addressed with Laminar Identification (Thompson et al. 2007a), Air Quality Indices and tracers from radiosondes (relative humidity) and aircraft, $\mathrm{CO}$ and $\mathrm{NO}_{\mathrm{y}}$.

3. In the case of Beltsville, how do July 2011 ozone structure and meteorological influences compare to 2006-2010, for which summertime sounding data are available? Statistics from LID and standard climatological indicators are analyzed.

The second section describes data sources and methods of analysis. The third section presents results and discussion related to Questions 1 and 2 above; the fourth section covers analyses related to Question 3. The fifth section is a summary.

\section{Measurements and methods of analysis}

\subsection{Ozone observations and data processing}

Ozone soundings in support of DISCOVER-AQ were made at Beltsville and Edgewood. All sounding data are public at http://www-air.larc.nasa.gov/cgi-bin/arcstat-d. The Beltsville soundings were made with a combination of Droplet Measurement Technologies (DMT) electrochemical concentration cell (ECC) ozonesondes and RS-92 radiosondes in 2011; the DMT sonde that was adopted at this site in 2010 is essentially the same instrument as previously supplied by the ENSCI Corporation. Ozonesondes at the Howard University Research Center (HURC) Beltsville site have been launched since 2004, as described in Morris et al. (2007), Thompson et al. (2007a), Thompson et al. (2007b) and Yorks et al. (2009). The soundings use a $0.5 \%$ buffered KI solution, that when combined with the ENSCI instrument, is shown in laboratory and field tests (Smit et al. 2007; Deshler et al. 2008; Smit (ASOPOS) 2011) to be accurate throughout the troposphere at $\sim 5 \%$.

The Edgewood ozone and pressure-temperature-humidity (PTU) soundings were made using DMT ozonesondes (Thompson et al. 2000; Johnson et al. 2002; Thompson et al. 2007c) coupled to Intermet IMet-1 radiosondes. A $1 \%$ buffered KI solution was employed which tends to produce ozone readings that are 5-10\% too high. The sonde readings were corrected, based on the performance of ENSCI sondes in a test chamber (Smit et al. 2007; cf Fig. 1 in Thompson et al. 2011; Smit (ASOPOS) 2011); the correction appears in Martins et al. (2013).

Total ozone column is obtained by integration of the sounding to burst, $\sim 10-15 \mathrm{hPa}$ in most cases, with a climatological add-on based on OMI, MLS and sonde profiles (McPeters and Labow 2012). Two other ozone column amounts are reported here: ozone within the boundary layer (BL); ozone integrated to the tropopause, designated TTOC, total tropospheric ozone column. The top of the BL is defined according to the altitude at which the thermal lapse rate first exceeds $7 \mathrm{~K} / \mathrm{km}$ (Martins et al. 2013; see also Heffter 1980). The column amounts are given in Dobson Units (DU); 1 DU $=2.69 \times 10^{16}$ molec $/ \mathrm{cm}^{2}$.

For the tropopause, an ozonopause criterion is employed, similar to that used by Browell and coworkers (Browell et al. 1996; Fenn et al. 1999). Following the ozone mixing ratio from troposphere toward the lower stratosphere, the largest gradient over a $0.5 \mathrm{~km}$ interval is taken as the tropopause as long as ozone above it remains at $100 \mathrm{ppbv}$ or more. The ozonopause (Fig. 1a, b) is typically 1-2 km lower than a thermal-lapse-rate tropopause (not shown) during DISCOVER-AQ in 2011. Exceptions to a well-defined ozonopause occur when sharplydefined layers of high-ozone air appear within the troposphere below the stratosphere-down 

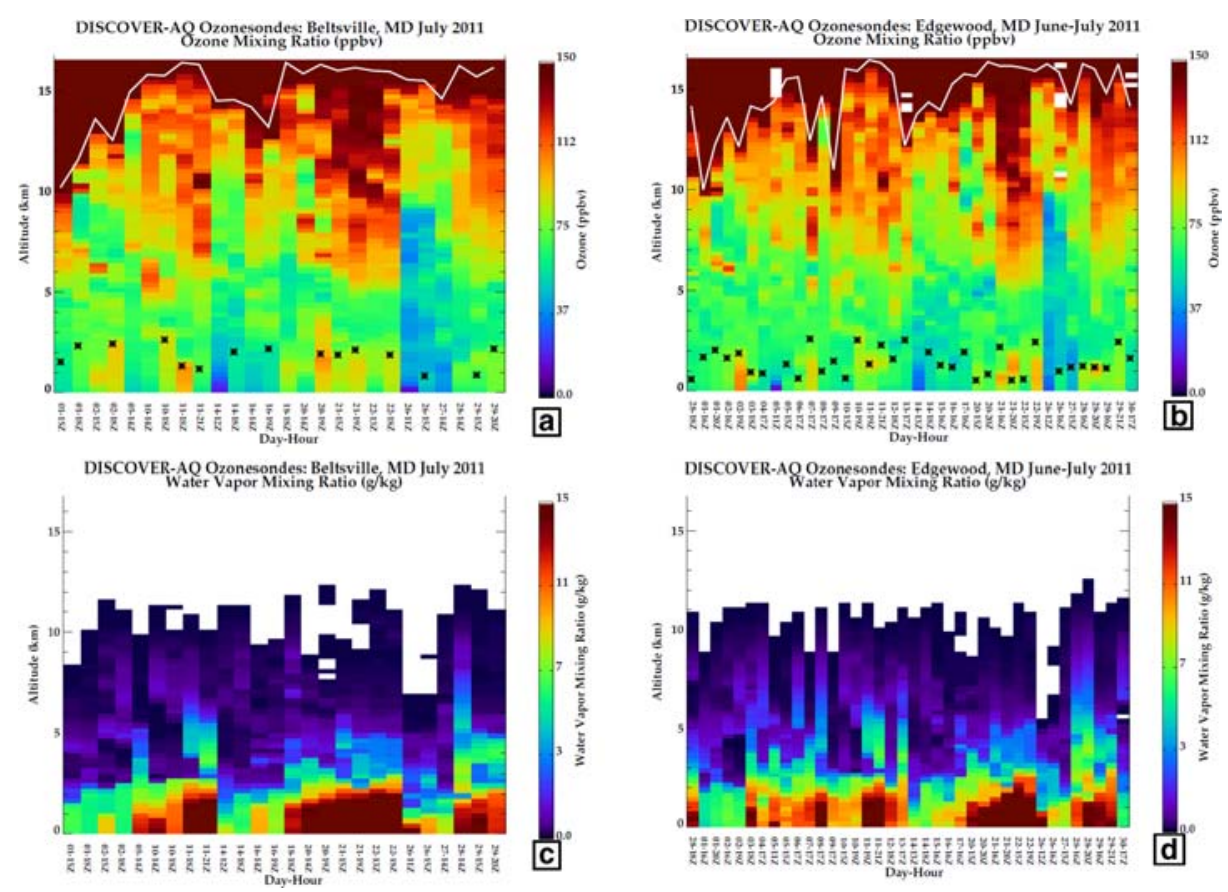

Fig. 1 Curtains of ozone mixing ratio (scale in ppbv) for segments averaged over $0.25 \mathrm{~km}$ from soundings taken during July 2011 DISCOVER-AQ over a Beltsville, MD; b Edgewood, MD. The tropopause based on an ozonopause (see text) appears in white. The boundary layer height (BLH) is given by Asterisk. Curtains of water vapor mixing ratio (scale in $\mathrm{g} / \mathrm{kg}$ ) for segments averaged over $0.25 \mathrm{~km}$ from soundings taken during July 2011 DISCOVER-AQ over c Beltsville, MD; d Edgewood, MD

ozonopause, ie in 3-4 DISCOVER-AQ soundings a "double tropopause" appears (cf Thompson et al. 2007a, b; Yorks et al. 2009).

Surface ozone data at the HURC Beltsville site is obtained from a TEI 49i ozone analyzer that is operated by MDE. At Edgewood, surface ozone readings were taken from the Penn State University Nittany Atmospheric Trailer and Integrated Validation Experiment (NATIVE), with a TEI 49c analyzer. We also use ozone profiles from the NCAR 4-channel analyzer, along with $\mathrm{NO}_{\mathrm{y}}$ from the same instrument on the P-3 (Table 1); these were measured below $5 \mathrm{~km}$ over Edgewood and on spirals below $2 \mathrm{~km}$ over Beltsville. The P-3 CO profiles are taken from the NASA Langley Differential Absorption Carbon Monoxide (DACOM) instrument (Table 1).

\subsection{Satellite data, data analysis and ancillary measurements}

OMI total ozone column from the TOMS v8.5 method is used for total ozone comparisons. For a tropospheric ozone column estimate, we use the TTOR (Schoeberl et al. 2007; Doughty et al. 2011) because it is well-characterized in the mid-Atlantic region (Normile et al. 2014, in review). TTOR data are available for about half the days of July 2011 at the website: ftp://hyperion.gsfc.nasa.gov/pub/aura/tropo3. The TTOR product is assumed to represent column ozone from the surface to $200 \mathrm{hPa}$. Thus, comparisons with integrated ozone in the soundings use a smaller column than the TTOC that typically extends above $13 \mathrm{~km}(\sim 150 \mathrm{hPa})$. 
Laminar identification analysis of segments within the free troposphere (FT) for each sounding (LID, Thompson et al. 2007a, b; Luzik 2009; Yorks et al. 2009; Thompson et al. 2010; Thompson et al. 2011) have been used to determine a budget of likely origins: BL, stratospheric ozone, vertically mixed regional pollution. The LID technique, based on a formalism introduced by Teitelbaum et al. (1994), uses normalized profiles of ozone and potential temperature anomalies to infer the presence of a wave and its associated mechanism. A lamina that is affected by a displacement designated as a Gravity Wave (GW) represents vertical mixing. For summer conditions in the mid-Atlantic, this is likely to occur during deep convection or mixing between the BL and lower free troposphere (LFT). Horizontal displacements, associated with a Rossby Wave (RW) designation, usually represent advection of stratospheric air or ozone pollution transported from upwind. Stratospheric influences in northeastern North American soundings during INTEX-A (Singh et al. 2006) are described in Thompson et al. (2007a, b) where $\sim 25 \%$ of summertime tropospheric ozone from soundings originated from the stratosphere. Detailed observations of stratospheric influence in summertime Beltsville soundings (2004-2007) appear in Yorks et al. (2009). Ozone in vertical layers that do not correspond to BL, GW or RW are labeled as "Residual," corresponding to air parcels containing background air which is aged enough that dynamical origins cannot be distinguished.

In Section 4, where various meteorological parameters for July 2011 are compared to JuneJuly-August (JJA) of years 2006-2010, anomalies for each year are determined graphically at http://www.esrl.noaa.gov/psd/data/composites/hour/. NCEP/NCAR Reanalysis fields are the basis for the imagery presented here.

\section{Results for DISCOVER-AQ (July 2011)}

In this section satellite-sounding comparisons are presented (Section 3.1) along with interpretations of ozone variability using the meteorologically oriented LID (Section 3.2). The general findings from LID are that convective and advective influences occur at different levels within a single sounding, creating a complex structure. Confirmation of meteorological signatures in the structure of individual profiles appears in Section 3.3 where case studies using aircraft data with the sondes are described in detail.

\subsection{Ozone profile overview and satellite product comparisons}

\subsubsection{Sonde profiles and OMI-based satellite comparisons}

Day to day ozone vertical structure recorded by the sondes launched in Beltsville (hereafter BV) and Edgewood (hereafter EW) appear in Fig. 1, where mixing ratio, averaged in $0.25 \mathrm{~km}$ segments, is depicted. There is only one profile at BV (Fig. 1a) between 3 and 10 July, compared to six at EW (Fig. 1b). Water vapor mixing ratios are also displayed (Fig 1c, d). The period 23-25 July was relatively unpolluted; no aircraft flights or sonde launches were conducted. On most other days sampling at both stations followed the same protocol, with two launches made as the P-3 spiraled down overhead. The repetitive route of the P-3 (http://www.nasa.gov/mission_pages/discover-aq/ overview/index.html; see also Fig. 1 in Martins et al. 2013) visited BV first, followed by spiraling over 3 additional sites to the north near Interstate-95 before starting the EW spiral that sampled down to $300 \mathrm{~m}$. The BV and EW sites are $\sim 70 \mathrm{~km}$ apart and were normally sampled with a 1.25 -h interval. 
Table 2 Summary of July 2011 ozone, with P-3 flight days in red (first column), Air Quality code (colors defined in first row)

\begin{tabular}{|c|c|c|c|c|}
\hline $0-60$ ppbv & 61-75 ppbv & 76-95 ppbv & 96-115 ppbv & \\
\hline Date & EW 8-hr Max (ppbv) & BV 8 & ar Max (ppbv) & Case Studies \\
\hline 01 July 2011 & 73.8 & & 68.6 & \multirow{2}{*}{$\begin{array}{l}\text { Pollution Episode } 1 \\
\text { (Section 3.3.1) }\end{array}$} \\
\hline 02 July 2011 & 96.4 & & 88.1 & \\
\hline 03 July 2011 & 73.0 & & 62.3 & \\
\hline 04 July 2011 & 50.3 & & 50.0 & \\
\hline 05 July 2011 & 89.5 & & 72.5 & \\
\hline 06 July 2011 & 75.0 & & 67.5 & \\
\hline 07 July 2011 & 86.8 & & 94.0 & \\
\hline 08 July 2011 & 54.5 & & 53.6 & \\
\hline 09 July 2011 & 61.5 & & 57.4 & \\
\hline 10 July 2011 & 68.9 & & 73.4 & \multirow{2}{*}{$\begin{array}{l}\text { Pollution Episode } 2 \\
\text { (Section 3.3.2) }\end{array}$} \\
\hline 11 July 2011 & 64.5 & & 75.6 & \\
\hline 12 July 2011 & 63.8 & & 63.4 & \\
\hline 13 July 2011 & 52.5 & & 59.8 & \\
\hline 14 July 2011 & 51.5 & & 61.8 & \multirow{3}{*}{$\begin{array}{l}\text { Clean Air } \\
\text { (Section 3.3.3) }\end{array}$} \\
\hline 15 July 2011 & 65.8 & & 52.6 & \\
\hline 16 July 2011 & 54.2 & & 49.9 & \\
\hline 17 July 2011 & 52.9 & & 54.9 & \\
\hline 18 July 2011 & 83.6 & & 75.4 & \\
\hline 19 July 2011 & 76.1 & & 62.8 & \\
\hline 20 July 2011 & 75.6 & & 80.6 & \\
\hline 21 July 2011 & 72.8 & & 78.9 & \multirow{2}{*}{$\begin{array}{l}\text { Pollution Episode } 3 \\
\text { (Section 3.3.4) }\end{array}$} \\
\hline 22 July 2011 & 102.1 & & 74.0 & \\
\hline 23 July 2011 & 93.7 & & 69.4 & \\
\hline 24 July 2011 & 65.8 & & 59.9 & \\
\hline 25 July 2011 & 60.2 & & 52.6 & \\
\hline 26 July 2011 & 73.7 & & 70.3 & \\
\hline 27 July 2011 & 53.0 & & 48.9 & \\
\hline 28 July 2011 & 70.6 & & 75.6 & Pollution Eoisode 4 \\
\hline 29 July 2011 & 82.6 & & 71.4 & \\
\hline 30 July 2011 & 60.5 & & 54.5 & \\
\hline 31 July 2011 & 78.7 & & 63.0 & \\
\hline
\end{tabular}

In general the vertical structure at BV and EW appear similar. At both sites the tropopause layer (denoted by red-brown gradients in Fig. 1a, b), is usually located between 9 and $13 \mathrm{~km}$. Exceptions occurred on 10,11 and 26 July, when the transition appears to be above $14 \mathrm{~km}$. Inspection of the boundary layer height (BLH; stars in Fig. 1a, b) reveals that EW is usually lower in BLH and higher in ozone (see also Table 2). Low water vapor (Fig. 1c, d) $<3 \mathrm{~g} / \mathrm{kg}$ (relative humidity, $\mathrm{RH},<15 \%$ ) is a persistent feature, appearing below $5 \mathrm{~km}$ in 12 of 14 days sampled at BV and 16 of 30 days at EW.

In Fig. 2 total integrated ozone from the sondes and the OMI overpass column amounts are compared. In Fig. 2a 6 years of summer data are displayed with a coded launch number (Table 3) gives the corresponding launch date. The requirements of the sonde reaching $20 \mathrm{hPa}$ 

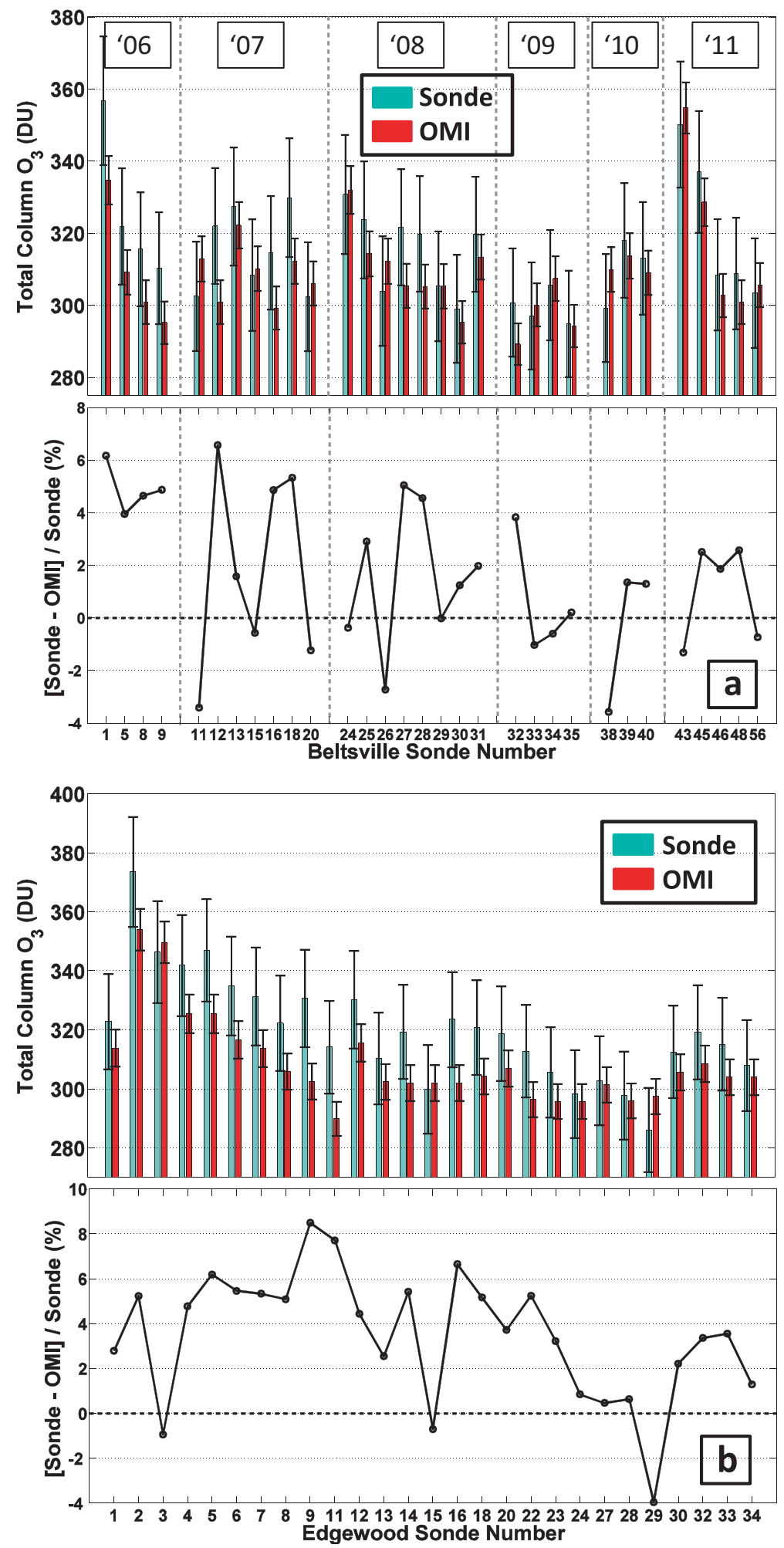
Fig. 2 OMI Overpass Comparison. a Total column ozone integrated from sonde (light blue), as described in text, for launches conducted from 2006 to 2011 over Beltsville, MD, and corresponding OMI overpass (red), both expressed in Dobson units (DU). b same as (a) for July 2011 only, for Edgewood, MD, sondes. Overpass comparison criteria were with $150 \mathrm{~km}$ and $3 \mathrm{~h}$ of launch. Error bars are 1-sigma. In lower panels no errors are given because the OMI reference is assumed absolutely correct

and a 150-km OMI overpass distance from launch site lead to only five BV coincidences (lower right in Fig. 2a) and 27 for EW (Fig. 2b) in July 2011. The error bar of OMI is $2 \%$, specified in black bars in the upper frame of each figure. The uncertainty in the sonde integral (aqua) is $5 \%$ (recommended in Smit et al. (2007) and Smit (ASOPOS) (2011)). The lower

Table 3 Key to profile labelsfor sondes at Beltsville (BV) and Edgewood (EW)

\begin{tabular}{|c|c|c|c|c|}
\hline BV Sonde & Year & Month & Day & Time (UTC) \\
\hline 1 & 2006 & 6 & 30 & 1827 \\
\hline 2 & 2006 & 7 & 16 & 1828 \\
\hline 3 & 2006 & 7 & 18 & 1753 \\
\hline 4 & 2006 & 7 & 20 & 1849 \\
\hline 5 & 2006 & 8 & 2 & 1918 \\
\hline 6 & 2006 & 8 & 15 & 1756 \\
\hline 7 & 2006 & 8 & 19 & 1806 \\
\hline 8 & 2006 & 8 & 25 & 1832 \\
\hline 9 & 2006 & 8 & 28 & 1817 \\
\hline 10 & 2007 & 6 & 27 & 1812 \\
\hline 11 & 2007 & 7 & 9 & 1813 \\
\hline 12 & 2007 & 7 & 10 & 2023 \\
\hline 13 & 2007 & 7 & 14 & 1806 \\
\hline 14 & 2007 & 7 & 16 & 1746 \\
\hline 15 & 2007 & 7 & 17 & 1844 \\
\hline 16 & 2007 & 7 & 19 & 1816 \\
\hline 17 & 2007 & 7 & 25 & 1814 \\
\hline 18 & 2007 & 7 & 26 & 1823 \\
\hline 19 & 2007 & 7 & 28 & 1812 \\
\hline 20 & 2007 & 8 & 2 & 1832 \\
\hline 21 & 2007 & 8 & 4 & 1821 \\
\hline 22 & 2007 & 8 & 5 & 1725 \\
\hline 23 & 2007 & 8 & 6 & 1828 \\
\hline 24 & 2008 & 7 & 2 & 1827 \\
\hline 25 & 2008 & 7 & 8 & 1924 \\
\hline 26 & 2008 & 7 & 12 & 1809 \\
\hline 27 & 2008 & 7 & 17 & 1838 \\
\hline 28 & 2008 & 7 & 18 & 1840 \\
\hline 29 & 2008 & 8 & 4 & 1841 \\
\hline 30 & 2008 & 8 & 5 & 1822 \\
\hline 31 & 2008 & 8 & 18 & 1817 \\
\hline 32 & 2009 & 6 & 25 & 1841 \\
\hline 33 & 2009 & 7 & 15 & 1844 \\
\hline 34 & 2009 & 8 & 4 & 1827 \\
\hline
\end{tabular}


Table 3 (continued)

\begin{tabular}{|c|c|c|c|c|}
\hline 35 & 2009 & 8 & 10 & 1758 \\
\hline 36 & 2009 & 8 & 18 & 1837 \\
\hline 37 & 2010 & 6 & 18 & 1811 \\
\hline 38 & 2010 & 6 & 20 & 2020 \\
\hline 39 & 2010 & 6 & 21 & 2014 \\
\hline 40 & 2010 & 8 & 9 & 1746 \\
\hline 41 & 2010 & 8 & 10 & 1754 \\
\hline 42 & 2010 & 8 & 21 & 1801 \\
\hline 43 & 2011 & 7 & 1 & 1501 \\
\hline 44 & 2011 & 7 & 1 & 1853 \\
\hline 45 & 2011 & 7 & 2 & 1850 \\
\hline 46 & 2011 & 7 & 10 & 1831 \\
\hline 47 & 2011 & 7 & 11 & 1800 \\
\hline 48 & 2011 & 7 & 11 & 2134 \\
\hline 49 & 2011 & 7 & 14 & 1800 \\
\hline 50 & 2011 & 7 & 16 & 1921 \\
\hline 51 & 2011 & 7 & 20 & 1915 \\
\hline 52 & 2011 & 7 & 21 & 1522 \\
\hline 53 & 2011 & 7 & 21 & 1941 \\
\hline 54 & 2011 & 7 & 22 & 1819 \\
\hline 55 & 2011 & 7 & 26 & 1543 \\
\hline 56 & 2011 & 7 & 29 & 1524 \\
\hline 57 & 2011 & 7 & 29 & 2009 \\
\hline EW Sonde & Year & Month & Day & Time (UTC) \\
\hline 1 & 2011 & 6 & 28 & 1807 \\
\hline 2 & 2011 & 7 & 1 & 1612 \\
\hline 3 & 2011 & 7 & 1 & 2010 \\
\hline 4 & 2011 & 7 & 2 & 1602 \\
\hline 5 & 2011 & 7 & 2 & 1944 \\
\hline 6 & 2011 & 7 & 3 & 1824 \\
\hline 7 & 2011 & 7 & 4 & 1717 \\
\hline 8 & 2011 & 7 & 5 & 1516 \\
\hline 9 & 2011 & 7 & 6 & 1716 \\
\hline 10 & 2011 & 7 & 7 & 1758 \\
\hline 11 & 2011 & 7 & 8 & 1706 \\
\hline 12 & 2011 & 7 & 9 & 1751 \\
\hline 13 & 2011 & 7 & 10 & 1542 \\
\hline 14 & 2011 & 7 & 10 & 1933 \\
\hline 15 & 2011 & 7 & 11 & 1923 \\
\hline 16 & 2011 & 7 & 11 & 2132 \\
\hline 17 & 2011 & 7 & 12 & 1814 \\
\hline 18 & 2011 & 7 & 13 & 1706 \\
\hline 19 & 2011 & 7 & 14 & 1819 \\
\hline 20 & 2011 & 7 & 15 & 1655 \\
\hline 21 & 2011 & 7 & 16 & 1607 \\
\hline
\end{tabular}




\begin{tabular}{lllll} 
Table 3 (continued) & & & & \\
\hline 22 & 2011 & 7 & 17 & 1648 \\
23 & 2011 & 7 & 20 & 1535 \\
24 & 2011 & 7 & 20 & 2032 \\
25 & 2011 & 7 & 21 & 1631 \\
26 & 2011 & 7 & 21 & 2050 \\
27 & 2011 & 7 & 22 & 1507 \\
28 & 2011 & 7 & 22 & 1938 \\
29 & 2011 & 7 & 26 & 1654 \\
30 & 2011 & 7 & 27 & 1536 \\
31 & 2011 & 7 & 28 & 1605 \\
32 & 2011 & 7 & 28 & 2019 \\
33 & 2011 & 7 & 29 & 1638 \\
34 & 2011 & 7 & 29 & 2121 \\
35 & 2011 & 7 & 30 & 1756 \\
\hline
\end{tabular}

frames in Fig. 2a and b are \% differences between sonde and $\mathrm{OMI}$ from [total $\mathrm{O}_{3}$ (sonde)-total $\left.\mathrm{O}_{3}(\mathrm{OMI})\right] /$ total $\mathrm{O}_{3}$ (sonde).

In several prior studies (Doughty et al. 2011; Thompson et al. 2012) we compared the TTOR (Schoeberl et al. 2007) tropospheric ozone product based on subtracting a trajectorymapped MLS stratospheric ozone column from OMI total ozone. To avoid complexities in defining the tropopause, Schoeberl et al. (2007) report TTOR as an integrated ozone column from surface to $200 \mathrm{hPa}$. The sonde ozone amounts are compared to archived TTOR in Fig. 3. At BV, except for one unusually clean day (14 July, Profile 49) the discrepancy between sondes integrated to $200 \mathrm{hPa}$ and TTOR averages $10 \%$. As with total ozone column comparisons at EW (24 of 27 profiles in Fig. 2b), the satellite column, TTOR, over EW usually runs low relative to the sondes (Fig. 3b). The mean absolute error is $10 \%$, similar to $\mathrm{BV}$; however, for 9 of $15 \mathrm{EW}$ profiles TTOR differs from sonde ozone by more than $15 \%$. The sonde-integrated column at EW for 5 of 15 comparisons exceeds TTOR by 10 DU or more. Given a $5 \%$ uncertainty in the ozone column amounts from the sondes, these discrepancies are statistically significant.

\subsubsection{Vertical ozone structure-Beltsville vs. Edgewood comparisons}

Insight into possible causes for sonde-TTOR discrepancy comes from examining individual profiles for days when TTOR is greater than the integrated sonde (Fig. 4, violet lines) and when TTOR is less than the corresponding sounding (blue in Fig. 4a; multi-color in Fig. 4b). The BV deviations from the mean tend to be more uniformly above or below the mean BV profile. Indeed, Martins et al. (2013) (cf Chatfield and Esswein 2012), examining BV and EW profiles from DISCOVER-AQ, found a robust relationship between ozone at 7-10 km and ozone from the surface to $3 \mathrm{~km}$. Correlation coefficients for mean mixing ratios in the two segments was $\mathrm{r}^{2}=$ $0.42( \pm 0.09)$ for BV, $0.43( \pm 0.09)$ at EW. Martins et al. (2013) also point out that for 3-6 km at $\mathrm{EW}$, ozone is not correlated with the surface- $3 \mathrm{~km}$ and $7-10 \mathrm{~km}$ segments. One explanation is that the 3-6 km layer over EW can be decoupled from the surface by processes like the bay breeze (as in dark green profile, Fig. 4b, Stauffer et al. 2012).

For EW, the soundings in Fig. 4b display a more complex relationship with the mean profile than for BV. Four soundings in which lower tropospheric ozone exceeded 70 ppbv 

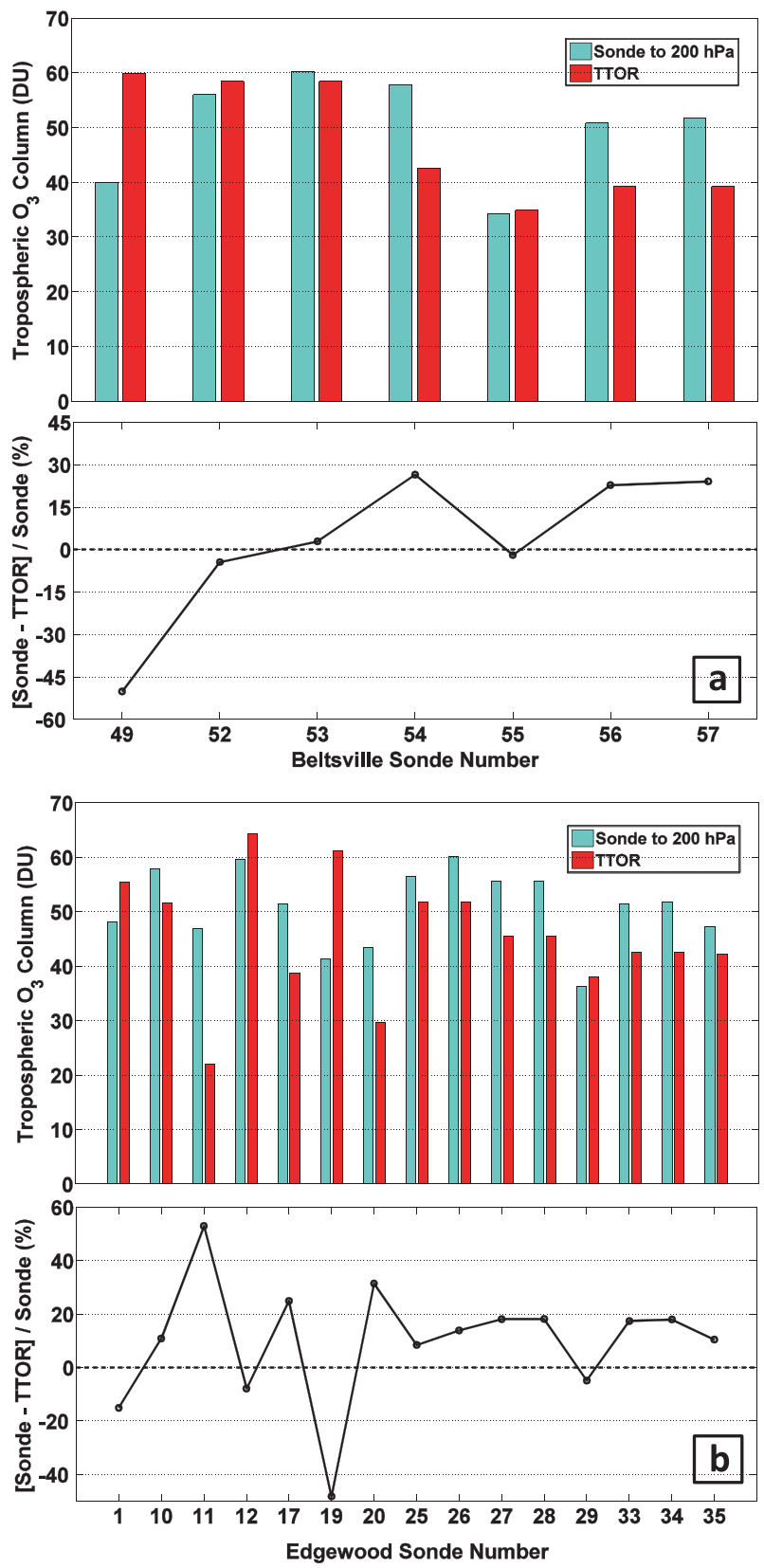

Fig. 3 TTOR Comparison. a Tropospheric (surface to $200 \mathrm{hPa}$ ) ozone columns (light blue) in Dobson units [DU] for Beltsville, Maryland, derived from ozonesonde launches in 2006 to 2011. TTOR (trajectory-enhanced tropospheric ozone residual) product based on an OMI-MLS difference (red), is compared. b same for Edgewood, Maryland, during the July 2011 DISCOVER-AQ campaign

below $2 \mathrm{~km}$ (Fig. 4b), took place on 7, 21 (earlier of two launches), 22 (later launch) and 29 July (later launch). Above $6 \mathrm{~km}$, these soundings also display $>70 \mathrm{ppbv}$ mixing ratio but not 


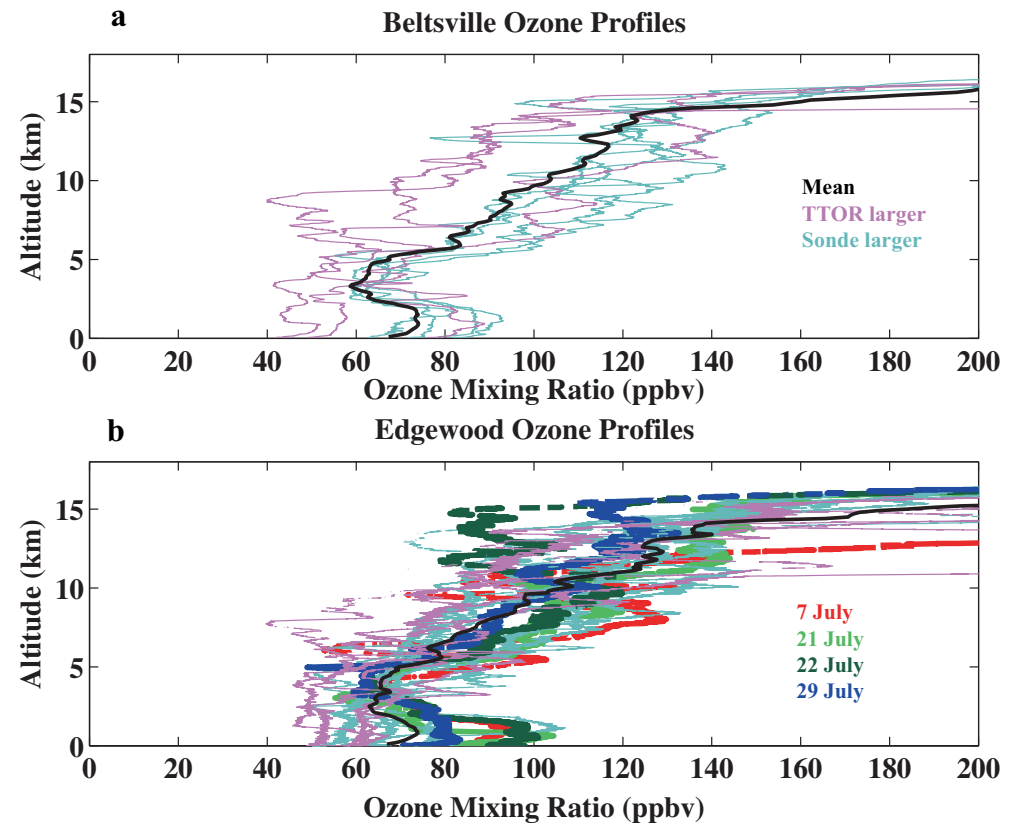

Fig. 4 Vertical ozone distribution from soundings over Beltsville (a) during DISCOVER-AQ; Edgewood (b). The bold profile represents the mean over all July 2011 soundings. Individual profiles for the days for which integrated sonde column ozone (to $200 \mathrm{hPa}$ ) exceeds the satellite TTOR measurement are in blue. For days with TTOR greater than the sonde, profiles are in violet. At Edgewood, four days for which sondes exceed TTOR are discussed in text: red: 7 July; light green, 21 July; dark green, 22 July; blue, 29 July

consistently. The 22 July (dark green) and 29 July (blue) profiles are mostly less than the mean above $6 \mathrm{~km}$. Conversely, two profiles (light blue in Fig. 4b) for which the sonde column exceeds TTOR are less than the mean near the surface. Thus, it appears that the known difficulty in detecting BL ozone is not necessarily the reason for large TTOR-sonde

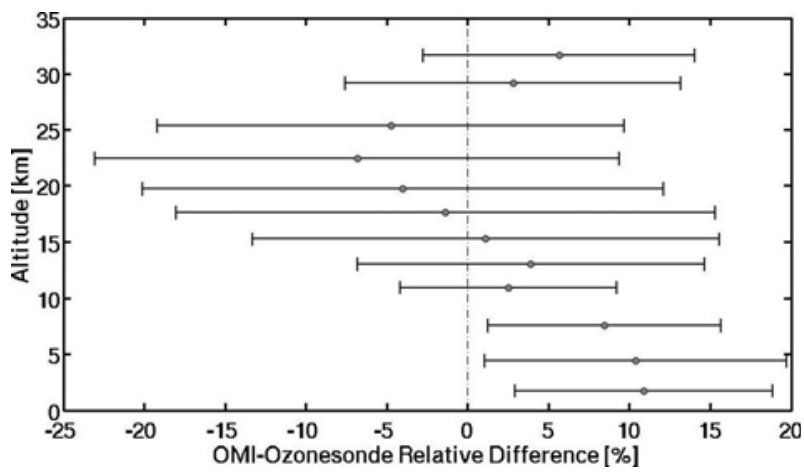

Fig. 5 A comparison of ozone profiles from the OMI satellite overpasses with 24 corresponding Edgewood soundings. The coincidence criteria were a median distance and time from the satellite of $300 \mathrm{~km}$ and $3 \mathrm{~h}$, respectively. OMI averaging kernel matrices are used to account for changes in OMI vertical sensitivity. The analyses are based on OMO3PR (version 003) data available at http://disc.sci.gsfc.nasa.gov/, with standard quality flags including cloud screening 

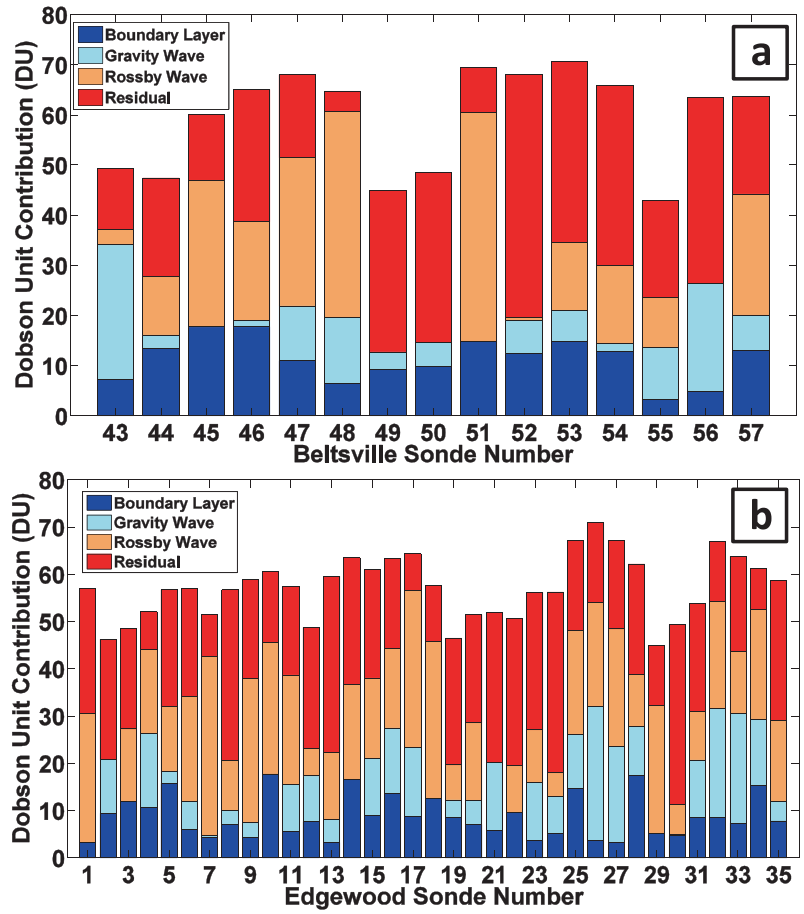

Fig. 6 LID Ozone Budgets for DISCOVER-AQ ozonesondes. a Tropospheric ozone budgets for Beltsville, Maryland, based on the Laminar Identification (LID) method, as described in (Thompson et al. 2007a, b; 2010) during DISCOVER-AQ, July 2011. Each bar represents total tropospheric ozone column (TTOC, to the tropopause depicted in Fig. 1) in Dobson units (DU). b as for (a) over Edgewood, MD, in July 2011. The dark blue column corresponds to the amount of ozone within the boundary layer (BL). The total amount of ozone in segments identified as influenced by gravity waves (GW) by LID is light blue. The total amount of ozone in segments identified by LID as influenced by Rossby waves (RW) is given in orange. The residual amount of column ozone, in layers that are not in the BL or affected by GW or RW, is red. The latter includes ozone that is recently (up to 7 days, as described in Teitelbaum et al. (1994) and Thompson et al. (2007a; 2010)) advected into the region or is considered a background amount with origins too old to be determined by LID. The number of soundings with LID analysis exceeds those in Figs. 2 and 3 where only soundings near Aura overpasses are illustrated

discrepancies (Fig. 3; Reed et al. 2013). The relationship between EW sondes and ozone "profiles" deconvolved from corresponding OMI overpasses presents something of a paradox (Fig. 5). First, for the sonde-OMI coincidences within a 3 h, 300-km window, the tropospheric segment of OMI exceeds the sonde whereas in the mid-stratosphere the opposite holds. Second, no statistically vertical gradient in OMI-sonde appears in the troposphere.

\subsection{Meteorological indicators and ozone variability}

In Fig. 6 the LID analyses for DISCOVER-AQ show considerable day-to-day variability at both BV (profiles 52-54 in Fig. 6a) and EW (profiles 25-28 in Fig. 6a), even within a few hours

Fig. 7 Sounding and aircraft profiles for 1-2 July. Sounding panels display ozone, RH, potential temperature and segments assigned to RW (light red) and GW (gray). Aircraft ozone, $\mathrm{CO}, \mathrm{NO}_{\mathrm{y}}$ profiles are from P-3 spirals. Note different aircraft altitude ranges (lower at BV) 


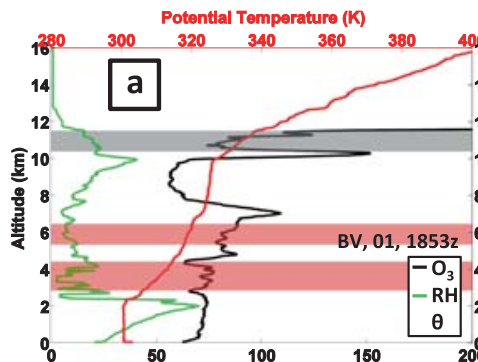

RH (\%), O M Mixlng Ratlo (ppbv)

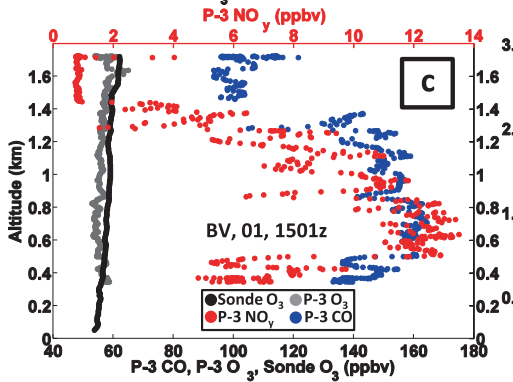

$\mathrm{P}-3$ NO (ppbv)
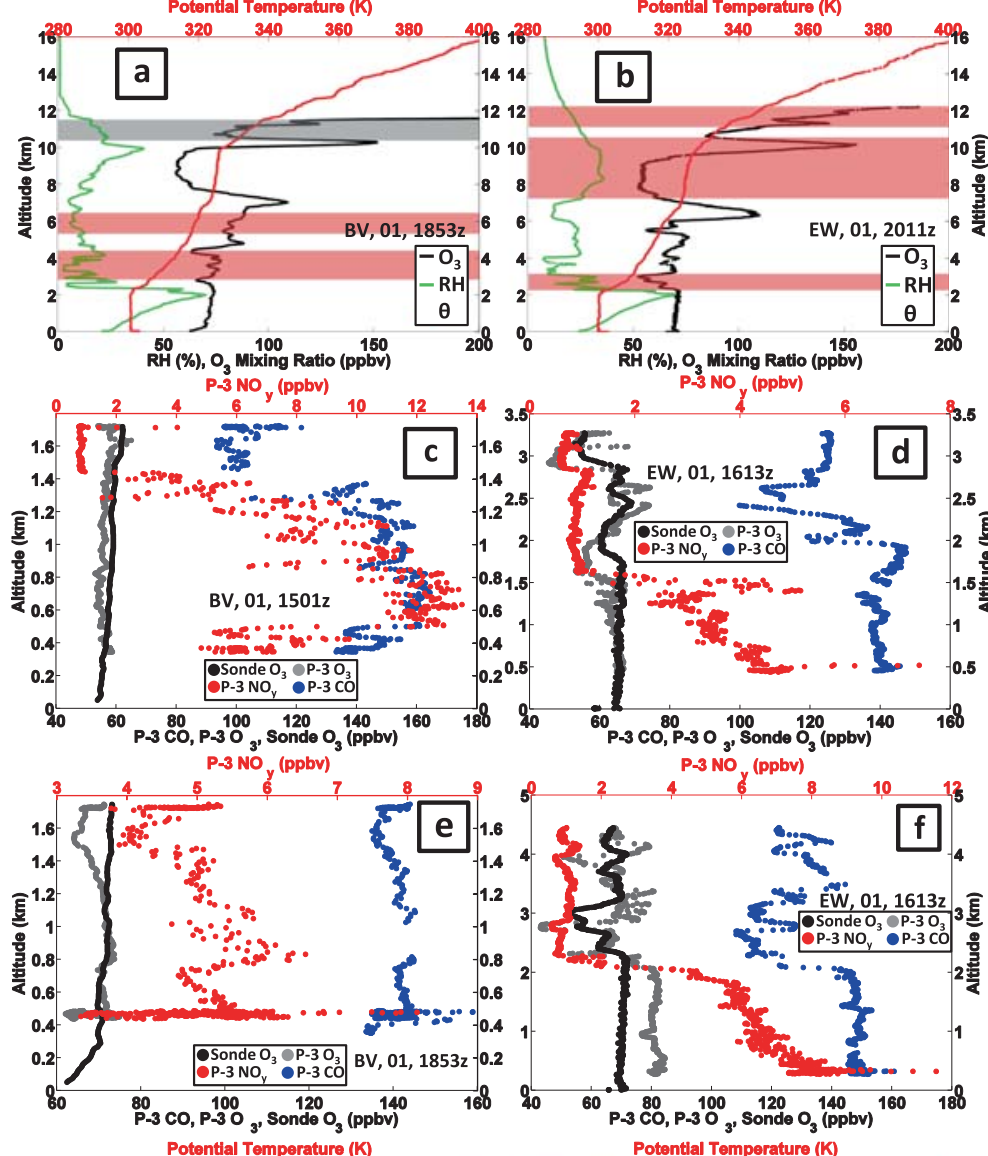

RH (\%), O $\stackrel{100}{100} \underset{150}{150}$

$\mathrm{P}-3 \mathrm{NO}_{\mathrm{y}}$ (ppbv)

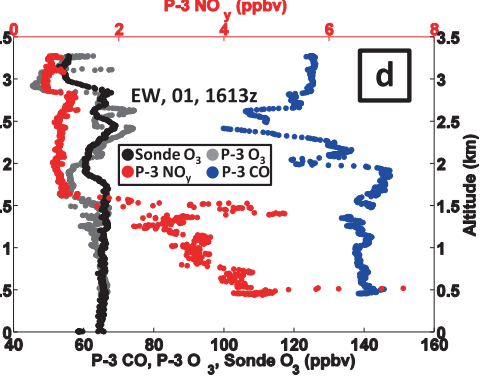

$\mathrm{P}=3 \mathrm{NO}$ (ppbv)
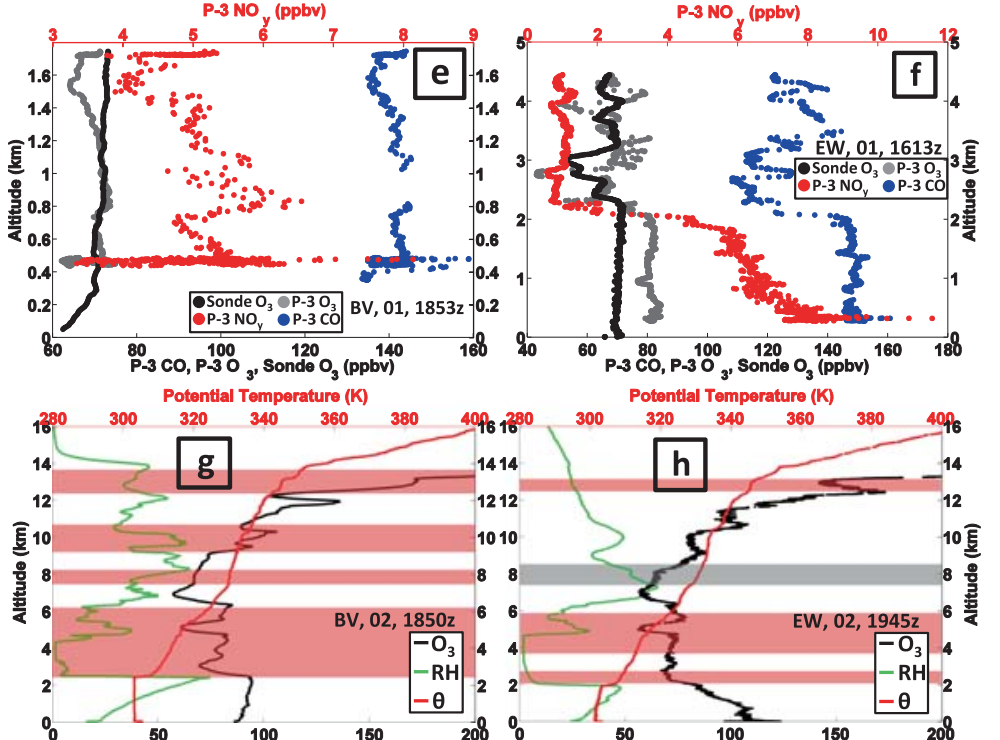

RH (\%), O $\stackrel{100}{100} \begin{array}{r}150 \\ \text { MIxlng Ratlo (ppbv) }\end{array}$

$\mathrm{P}-3 \mathrm{NO}_{y}$ (ppbv)

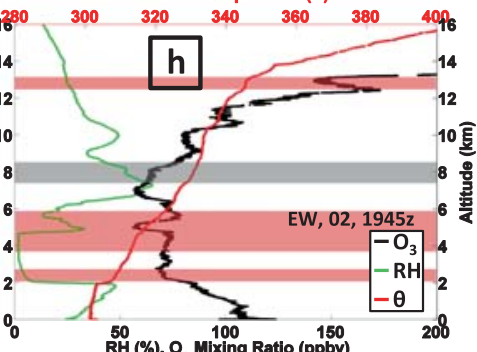

50
$\mathrm{RH}$

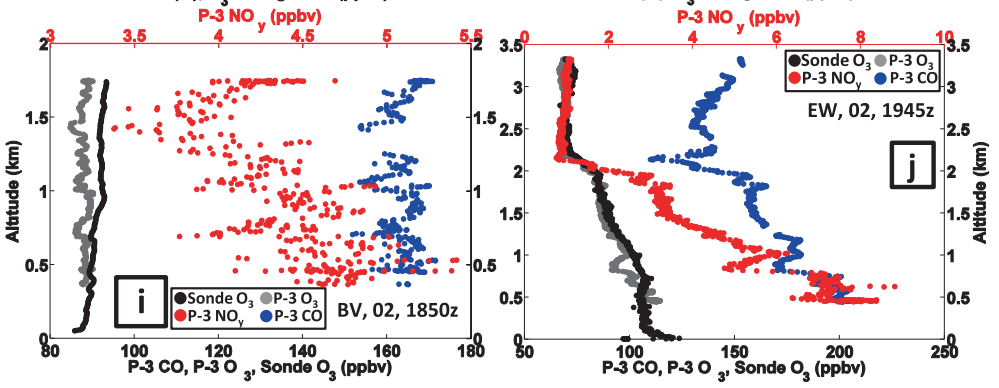


Table 4 Summary of case study aircraft data below $2 \mathrm{~km}$

\begin{tabular}{|c|c|}
\hline Dates & Summary of variations within period \\
\hline Pollution Period \#1, 1-2 July & $\begin{array}{l}\text { Starts with } \mathrm{BV} \mathrm{CO} / \mathrm{NO}_{\mathrm{y}} \text { higher at } \mathrm{BV} \text { than } \mathrm{EW} \text {. Transitions to } \\
\text { similar } \mathrm{CO} / \mathrm{NO}_{\mathrm{y}} \text { later on } 1 \text { July before } 2 \text { July becomes Code } \\
\text { Red at } \mathrm{EW} \text { with } \mathrm{NO}_{\mathrm{y}} \sim 8 \mathrm{ppbv} \text { at } \mathrm{EW} \text { compared to } \mathrm{BV} 5 \text { ppbv. }\end{array}$ \\
\hline Pollution Period \#2, 10-11 July & $\begin{array}{l}\text { Ozone similar on } 10 \text { July, but BV in BL has lower } \mathrm{CO} \text { and higher } \\
\mathrm{NO}_{\mathrm{y}} \text { than EW. On } 11 \text { July BV ozone } 20 \% \text { greater in } \mathrm{BL} \text { than } \mathrm{EW} \text {. } \\
\mathrm{CO} / \mathrm{NO}_{\mathrm{y}} \text { higher at } \mathrm{BV} \text {, presumably due to shallower BL, } \\
\text { less ventilation at } \mathrm{BV}\end{array}$ \\
\hline Clean Period, 14-16 July & $\begin{array}{l}\text { At } \mathrm{BV} \text { and } \mathrm{EW} \text {, ozone similar but } \mathrm{BV} \mathrm{CO} \text { higher and } \mathrm{NO}_{\mathrm{y}} \text { about twice } \\
\text { as high as EW. }\end{array}$ \\
\hline Pollution Period \#3, 20-22 July & $\begin{array}{l}20 \text { July }-\mathrm{BV} \text { more polluted with } 50 \text { ppbv more } \mathrm{CO} \text {, then transitions } \\
\text { to EW more polluted on } 21 \text { July, when ozone } \sim 110 \text { ppbv at } 1 \mathrm{~km} \text {, } \\
\text { exceeded BV by } 30 \text { ppbv. On } 22 \text { July ozone } 2 \times \text { higher at EW than } \\
\text { BV with later profile EW CO } 10 \% \text { higher than BV; BV NO } 25 \% \\
\text { higher than EW. }\end{array}$ \\
\hline
\end{tabular}

at each site, e.g. on 21 and 22 July. Edgewood soundings, with fewer gaps over July and generally similar tropospheric columns to those at BV, give an overview of the ozone situation. As for the profile structure at EW (Fig. 4b), examination of ozone budget segments in Fig. 6b, indicates that discrepancies between TTOR and sonde column amount do not follow a single pattern. For 21 July (earlier launch, profile 25) and 22 and 29 July (later launches, profiles 28 and 34), BL ozone exceeds 15 DU. The other 21, 22 and 29 July EW profiles $(26,27,34)$ are low in BL ozone with $>20$ DU ozone corresponding to GW segments (Fig. 6a). For the earlier 22 and 29 July profiles, launches were made before there was much ozone mixed into the BL although there was quite a bit of ozone above it. Over EW, layering in the latter part of 21 July was distinct from other sites sampled nearby by aircraft. He et al. (2014), using DISCOVERAQ aircraft data, point out that the expected ground level ozone ( $\sim 100 \mathrm{ppbv})$ did not materialize on 21 July episode (Section 3.3.4).

\subsection{Case studies on chemical variability}

Table 2 is a compilation of surface ozone statistics including Air Quality Index color codes and a list of representative pollution periods during DISCOVER-AQ. July 2011 started with a relatively low tropospheric ozone column (45 and 48 DU for the 1 July EW soundings in Fig. 6 profiles 2 and 3, 47 and 49 DU for the corresponding BV columns, profiles 43 and 44 in Fig. 6), followed by a pollution episode that developed on 2 July. Table 2 shows that on 2 July surface ozone exceeded 90 ppbv at both sites, but Code Red, defined by a 95 ppbv limit over $8 \mathrm{~h}$, appeared only at EW (Table 2). No Code Red violations occurred at BV in July 2011. A second polluted period prevailed on 10-11 July (BV profiles 46-48, EW profiles 31-34), followed by 9 days of more moderate conditions. Although it was not characterized by the highest surface ozone (78-90 ppbv ozone when the sondes were launched), a third high-ozone period coincided with the highest July tropospheric ozone columns, > 70 DU on 21 July, at BV (profiles 52 and 53) and EW (profiles 25 and 26, Fig. 6). The second EW Code Red occurred on 22 July (Table 2). The fourth elevated ozone period took place on 28 and 29 July (Fig. 6 with profiles 56 and 57 for BV, 31-34 for EW).

In Sections 3.3.1-3.3.4 the first three pollution episodes and one low-ozone "background" period (Table 2) are described with meteorological conditions, LID analyses, and 

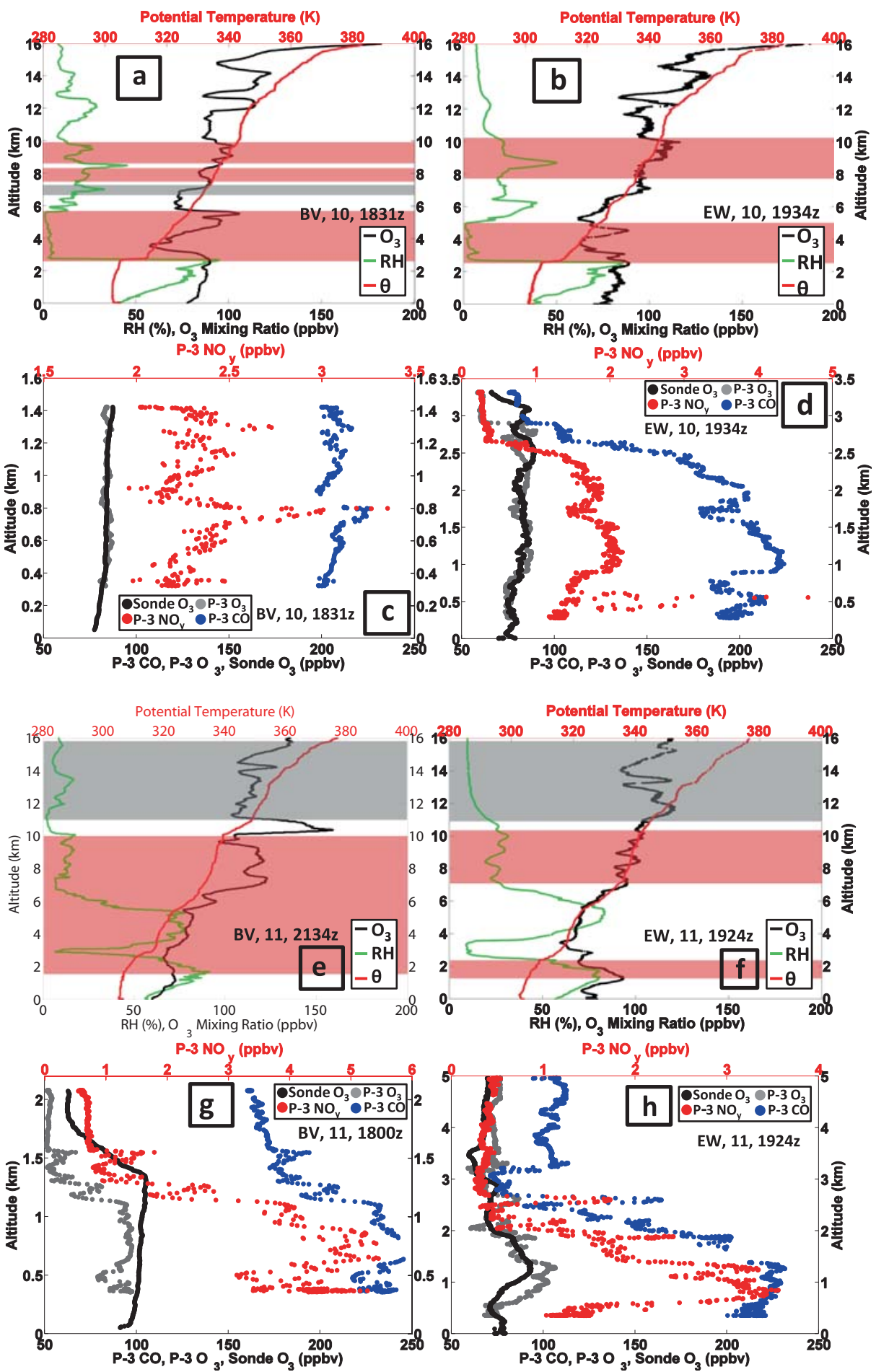

Fig. 8 As for Figure 7 with sounding and aircraft data for 10-11 July 2011 

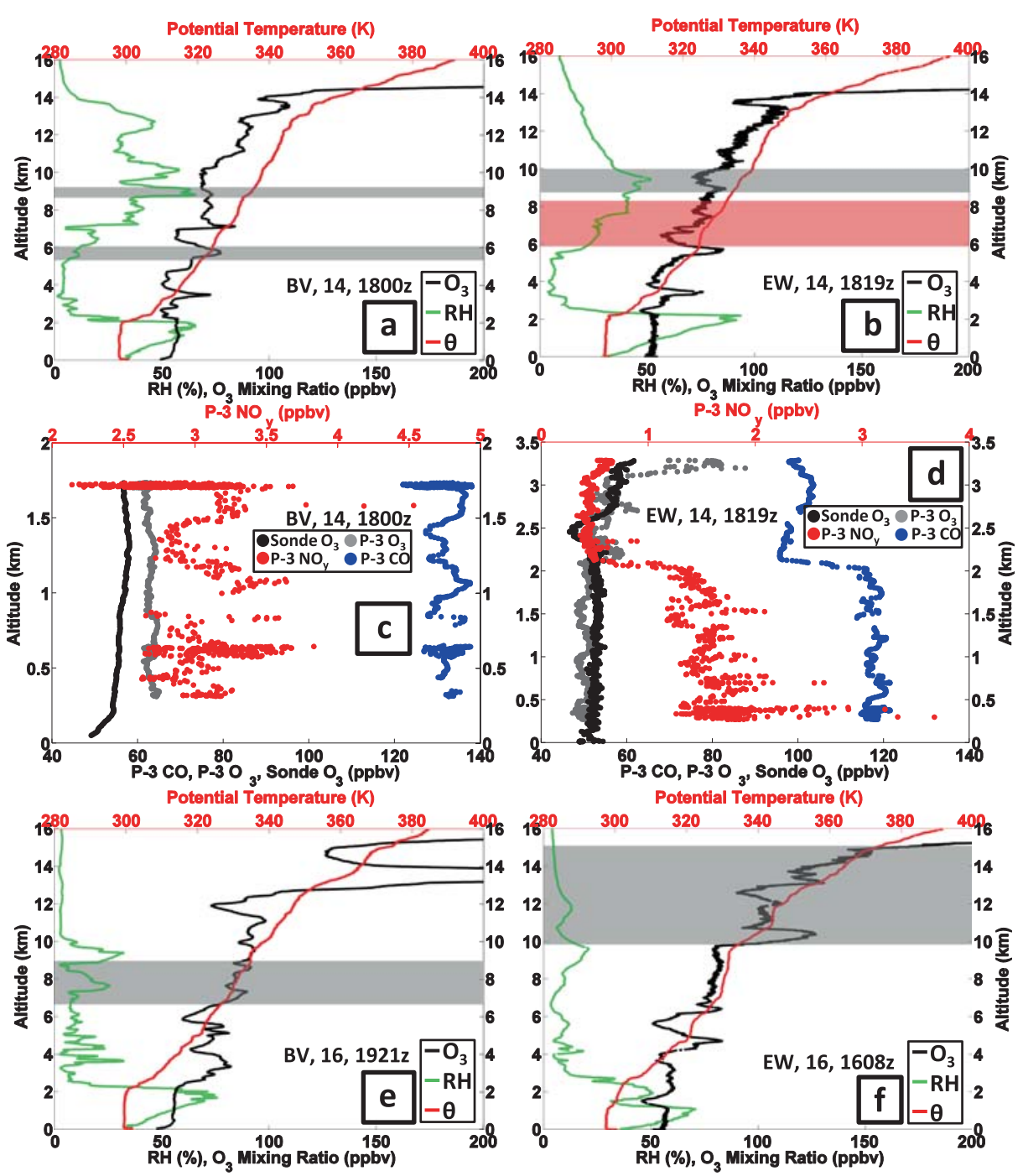

Fig. 9 As for Figure 7 with sounding and aircraft profiles for 14 July 2011

variability in $\mathrm{O}_{3}, \mathrm{H}_{2} \mathrm{O}, \mathrm{CO}$ and $\mathrm{NO}_{\mathrm{y}}$ profiles (below $4.5 \mathrm{~km}$ for the latter two measurements). A summary appears in Table 4. Pairs of ozone and RH profiles for days of sonde launches at both BV and EW are analyzed. In general the aircraft ozone and the sonde measurement are in close agreement. At both $\mathrm{BV}$ and $\mathrm{EW}$ the $\mathrm{BL}$ is often decoupled from the FT; aircraft $\mathrm{CO}$ and $\mathrm{NO}_{\mathrm{y}}$ profiles up to $2 \mathrm{~km}(\mathrm{BV})$ and $4.5 \mathrm{~km}(\mathrm{EW})$ display broadly similar vertical structure but hour-to-hour differences in stable layers (laminae) and other small scale features often differ.

\subsubsection{Pollution episode 1: 1-2 July}

On 30 June a cold front passed through the DISCOVER-AQ sampling area. With a high pressure system well-established by 2 July, 1 July could be characterized as a transition day 
(Oyola et al. 2014, in review). On 1 July a relatively low tropopause layer is indicated by the ozonopause (white lines in Fig. 1a, b). The earlier profiles at both BV (Fig. 1a) and EW (Fig. 1b) on 1 July are quite dry above $5 \mathrm{~km}$ as displayed in the corresponding $\mathrm{H}_{2} \mathrm{O}$ profiles (Fig. 1c, d). In the early profiles, GW activity is indicated between 5 and $10 \mathrm{~km}$ (not shown), suggesting vertical mixing. At BV surface ozone is $\sim 55 \mathrm{ppbv}$; in $\sim 4 \mathrm{~h}$, the sounding (Figs. 1a and $7 \mathrm{a}$ ) taken during the 2nd aircraft spiral show that BV near-surface ozone increased to $\sim 70 \mathrm{ppbv}$. A very dry layer at $3-4 \mathrm{~km}$ that is associated with RW in the first sounding remains in the second sounding (lower red shaded band in Fig. 7a). The dryness suggests stratospheric origins, an interpretation that is consistent with tracer data from the P-3. Although aircraft sampling over $\mathrm{BV}$ is restricted to less than $2 \mathrm{~km}$ (Fig. 7c), the earlier spiral displays a sharp decrease in $\mathrm{CO}$ and $\mathrm{NO}_{\mathrm{y}}$ at $1.3-1.4 \mathrm{~km}$. Above $1.4 \mathrm{~km}$ the $\mathrm{CO}$ mixing ratio drops from the first aircraft spiral, from
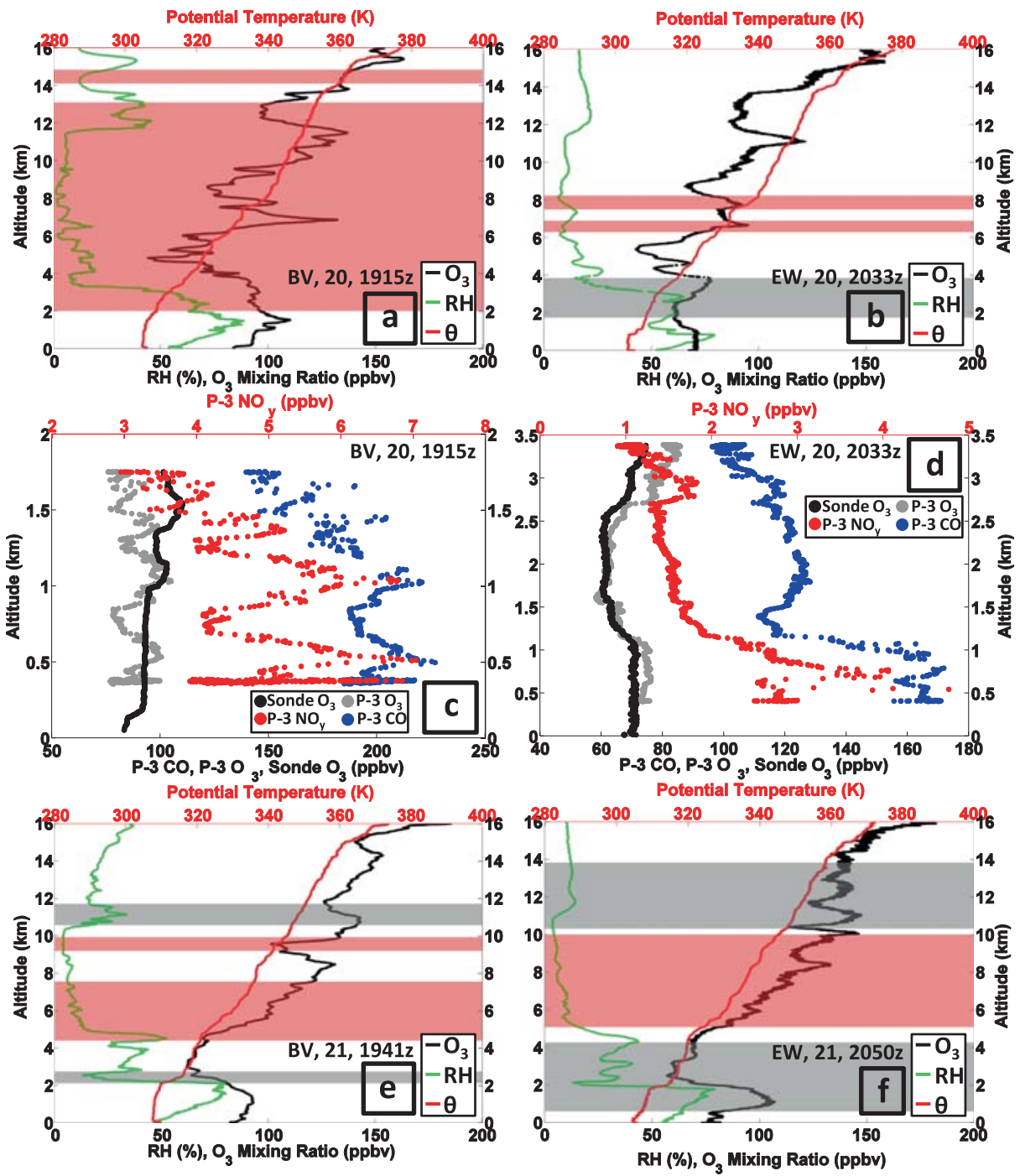

Fig. 10 As for Figure 7 with sounding and aircraft profiles for 20-22 July 2011 


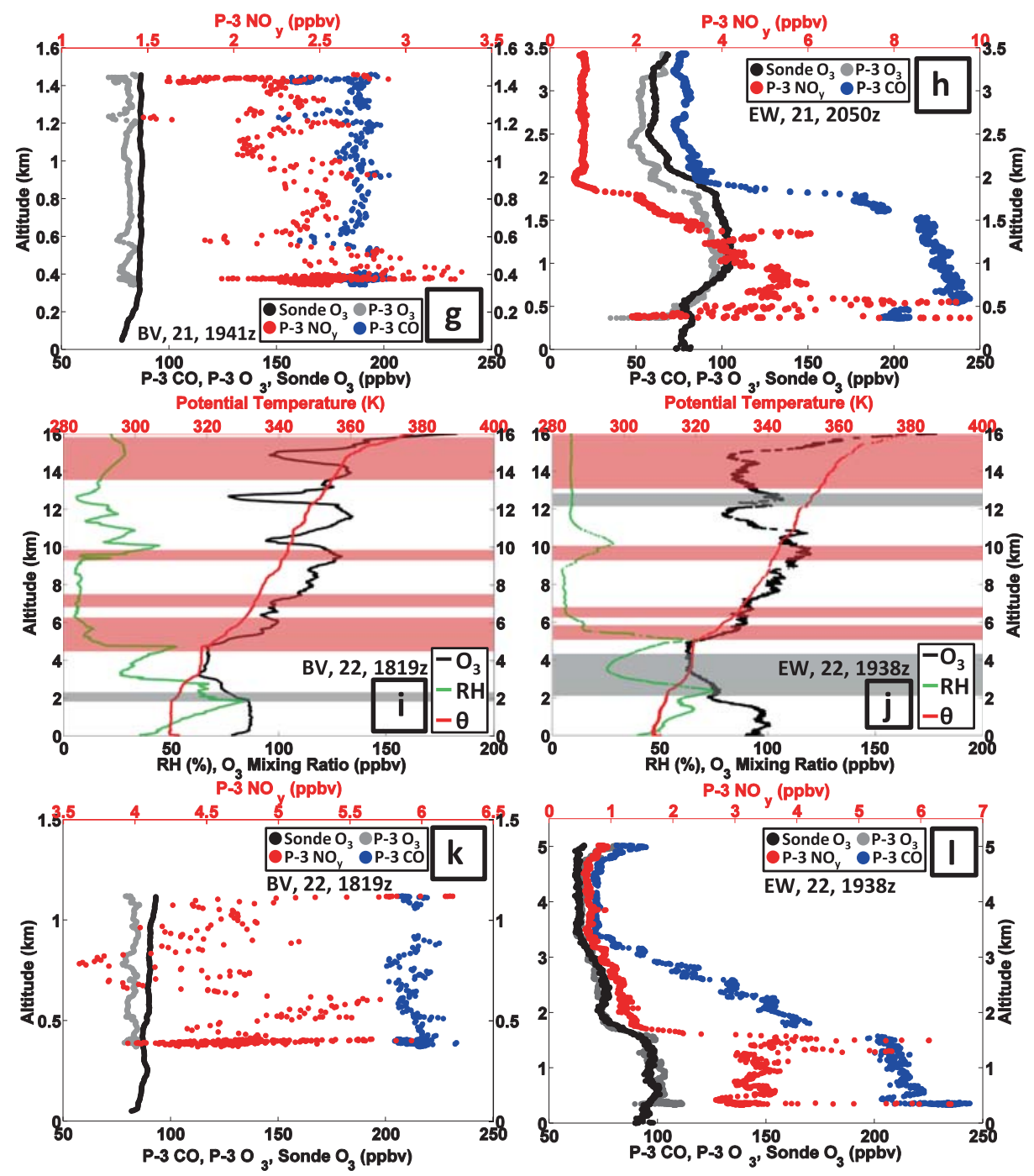

Fig. 10 (continued)

a mean $140 \mathrm{ppbv}$ in the BL to $\sim 100$ ppbv (Fig. 7c), a very low value for mid-latitude continental FT air (Browell et al. 1996). In the second BV aircraft spiral (Fig. 7e), $\mathrm{NO}_{\mathrm{y}}$ and $\mathrm{CO}$ are well mixed in BL and LFT. In Fig. 7e $\mathrm{NO}_{\mathrm{y}}$ is $4-5 \mathrm{ppbv}$ and $\mathrm{CO}$ is uniformly $135-145$ ppbv from $\sim 0.3 \mathrm{~km}$ to $1.8 \mathrm{~km}$.

On 1 July at EW, in the second sounding (Fig. 7b), there is a locally dry layer (RH $\sim 10 \%$ ) at 6-7 km that coincides with a $>100$-ppbv ozone layer at the lower-altitude end of an extended RW segment (red shading from $\sim 7$ to $10 \mathrm{~km}$ Fig. $7 \mathrm{~b}$ ). This EW sounding on 1 July mostly resembles the 2nd BV profile of 1 July (Fig. 7a), with a thin layer at $10 \mathrm{~km}$ exceeding $150 \mathrm{ppbv}$ at peak and a $\sim 60$ ppbv layer (moister than BV) at 8-10 km. P-3 aircraft spirals over EW begin at $3.2 \mathrm{~km}$ or above (Fig. 7d, f). As in the first BV spiral (Fig. 7c), CO over EW in the LFT is lower than in the BL, with a minimum $\sim 110$ ppbv at $2-2.5 \mathrm{~km}$ (Fig. $7 \mathrm{~d}$ ). This CO feature corresponds to a dry segment in the EW sounding $(\mathrm{RH}<10 \%$, Fig. $7 \mathrm{~b})$ and 1 ppbv $\mathrm{NO}_{\mathrm{y}}$ above 
$1.5 \mathrm{~km}$ in the P-3 spiral over EW (Fig. 7d); stratospheric origins are indicated. Thus, stratospheric influences are present even in the midst of a pollution episode; note the significant RW fraction in EW sonde 3 (later 1 July) in Fig. 6b. The second P-3 spirals record moderately high BL pollution over BV and EW (Fig. 7e, f), e.g. 7-10 ppbv $\mathrm{NO}_{\mathrm{y}}$ below $0.5 \mathrm{~km}$ at EW.

On 2 July, a day designed for overflying a developing pollution episode (Table 2), there was only a BV launch during the second P-3 circuit (Fig. 7g, i). The BV ozone profile (Fig. $7 \mathrm{~g}$ ) displays 4 red-shaded bands (RW) at altitudes with locally high ozone and moister air (RH $\sim 50 \%$, compared to $<30 \%$ ) than the day before. Isolated from the bay breeze (Stauffer et al. 2012) on 2 July, pollution does not develop at BV. Instead, the P-3 sampling over BV (Fig. 7i) reveals moderate, well-mixed pollution $(\mathrm{CO}=150-170 \mathrm{ppbv}$, $\mathrm{O}_{3}=80$ ppbv, 3.5-5.5 ppbv $\mathrm{NO}_{\mathrm{y}}$ ) from 0.38 to $1.8 \mathrm{~km}$.

The first EW sounding on 2 July (at 1802 UTC, not shown) was similar to the second set of BV and EW profiles on 1 July. However, there was a GW feature over EW in the sounding from 7 to $11.5 \mathrm{~km}$, indicating vertical mixing, and a RW segment from 2 to $6 \mathrm{~km}$, suggestive of advection. In the later EW profile (GW, gray shading at $8 \mathrm{~km}$ in Fig. $7 \mathrm{~h}$ ) the mixing may have contributed to enhanced ozone above $10 \mathrm{~km}$. Horizontal transport identified by Stauffer et al. (2012) as a bay-breeze on 2 July leads to 120 ppbv surface ozone at EW and an 8-h maximum of 96 ppbv (Table 2). The corresponding P-3 tracer spirals over EW (Fig. 7j) show ozone $>100$ ppbv near the surface with 200 ppbv $\mathrm{CO}$ and 4-8 ppbv $\mathrm{NO}_{\mathrm{y}}$ below $1.5 \mathrm{~km}$. Above $2 \mathrm{~km}$, the $\mathrm{P}-3$ records $\mathrm{CO}<120 \mathrm{ppbv}$ and $\mathrm{NO}_{\mathrm{y}}<1.5 \mathrm{ppbv}$ (Fig. 7j) and the EW sounding (Fig. 7h) shows 70 ppbv ozone and very dry air up to $5 \mathrm{~km}$.

\subsubsection{Pollution episode 2: 10-11 July}

A moderate ozone episode took place on 10-11 July, sampled by aircraft and launches at each station (Fig. 8). Only at EW were there two 10 July soundings; they do not diverge much from the 10 July BV profile (Fig. 8a) that took place an hour before the later EW launch (Fig. 8b). The BV ozone aircraft profile (1831 UTC, Fig. 8c) is nearly identical to the corresponding sounding in the BL, but $\mathrm{CO}$ is $\sim 200$ ppbv below $1.5 \mathrm{~km}$ with $2-3$ ppbv $\mathrm{NO}_{\mathrm{y}}$. There is considerable fine structure in ozone and $\theta$, with GW (gray shading) or RW (red shading) zones in all the 10 July soundings. Over EW (Fig. 8b) between 3 and $5 \mathrm{~km}$, moderate ozone in a very dry layer corresponds to a RW (red) signature, indicative of advection. The dryness suggests stratospheric origins, as does the P-3 profile (Fig. 8d) with

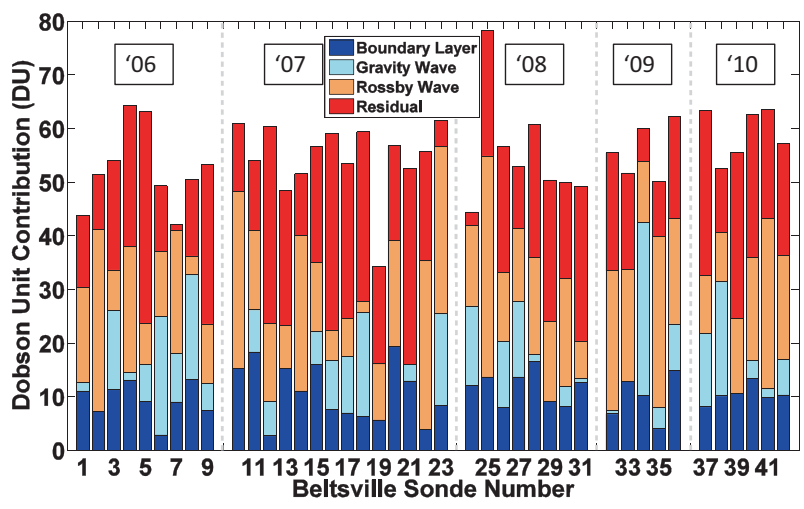

Fig. 11 Multi-year LID tropospheric ozone budgets for Beltsville, as in Fig. 6, except that all daytime soundings for JJA 2006-2011 are displayed. Annually averaged BL, GW and RW amounts appear in Table 5 
80 ppbv CO, which is approximately half the normal LFT CO concentration for the midAtlantic.

There were four soundings on 11 July, one BV and one EW sounding each in the 18001930 UTC period and again after 2100 UTC. As in the 1-2 July profiles there is a very dry layer at $3 \mathrm{~km}$ in all of the 11 July profiles. The earlier BV sounding has $\sim 100 \mathrm{ppbv}$ at the surface (not shown) whereas the corresponding EW profile is 80 ppbv (Fig. 8f), overlaid by a layer of moderate ozone, with a higher ozone layer above the BL at $1-2 \mathrm{~km}$. The BV P-3 profile (Fig. 8g) is polluted, with $90-100$ ppbv ozone, $\mathrm{CO}>225 \mathrm{ppbv}$ and $\mathrm{NO}_{\mathrm{y}}>5$ ppbv down to $0.35 \mathrm{~km}$. Both EW aircraft profiles (Fig. $8 \mathrm{~h}$ is the later one) resemble nearsurface BV CO and $\mathrm{NO}_{y}$ pollution. In a dry layer at $3 \mathrm{~km}, \mathrm{CO}$ over EW drops to $80 \mathrm{ppbv}$ with 0.5 ppb $\mathrm{NO}_{\mathrm{y}}$, suggesting stratospheric influence (RW band at $2 \mathrm{~km}$ in the sounding, Fig. 8f). As during the 1-2 July pollution episode, stratospheric influences persist within pollution.

\subsubsection{Cleaner air: 14-16 July}

The lowest tropospheric ozone columns, 45 DU, were sampled on 14 July (BV profile 49, EW profile 19 in Fig. 6), with the corresponding ozone, $\theta$ and $\mathrm{RH}$ profiles depicted in Fig. 9. The BV and EW profiles are mostly 50-60 ppbv from the surface to $8 \mathrm{~km}$ (Fig. 9a, b). On 14 July the $\mathrm{BL}$ is $\sim 2.5 \mathrm{~km}$ at both sites, above which is a very dry layer up to $\sim 6 \mathrm{~km}$. An interpretation of stratospheric impact is supported by the RW signature in the EW sounding (Fig. 9b). In Fig. $6 \mathrm{~b}$ the ozone RW budget for the 14 July EW sounding represents $25 \%$ of the ozone; the prior day, 13 July, more than half the ozone over EW was RW-classified. The air parcels sampled in the 14 July soundings can be considered as a background composition. Besides 50-60 ppbv aircraft ozone the corresponding P-3 spirals (1800-1830 UTC in Fig. 9c, d) display low pollution conditions with $130 \mathrm{ppbv}$ CO below $1.8 \mathrm{~km}$ at BV (Fig. 9c). Over EW (Fig. 9d) $\mathrm{CO}$ is $120 \mathrm{ppbv}$ from surface to $2 \mathrm{~km}$, dropping to $100 \mathrm{ppbv}$ from 2 to $3.4 \mathrm{~km}$. The 16 July soundings (Fig. 9e, f) are similar to those for 14 July but they display lower RH in much of the troposphere (Fig. 1c, d).

\subsubsection{Pollution episode 3: 20-22 July}

Stauffer et al. (2012) classify Edgewood as following an 'interrupted' bay breeze; on 19 July the 1-h maximum ozone was 108 ppbv. On 20 July the sole BV sounding (Fig. 10a) was richly

Table 5 Summary of LID ozone budgets from Beltsville JJA soundings (2006-2010) and Beltsville (BV) and Edgewood (EW) budgets, July 2011. Ozone is given in Dobson Units (DU)

\begin{tabular}{llllll}
\hline Year & BL (DU, \%) & GW (DU, \%) & RW (DU, \%) & Residual (DU,\%) & Total (DU) \\
\hline BV, 2006 & $9.36,17.8$ & $8.90,17.0$ & $15.6,29.8$ & $18.6,35.4$ & 52.4 \\
BV, 2007 & $10.7,19.5$ & $5.70,10.4$ & $15.7,28.8$ & $22.6,41.3$ & 54.6 \\
BV, 2008 & $11.7,21.2$ & $5.88,10.6$ & $17.9,32.3$ & $19.9,35.9$ & 55.3 \\
BV, 2009 & $9.74,17.4$ & $9.12,13.1$ & $21.9,39.2$ & $15.1,27.0$ & 55.9 \\
BV, 2010 & $10.4,17.6$ & $7.73,13.1$ & $17.4,29.5$ & $23.6,39.8$ & 59.1 \\
BV, July 2011 & $11.2,18.9$ & $7.76,13.1$ & $16.3,27.3$ & $24.2,40.7$ & 59.5 \\
EW, 7/11, All & $8.66,15.2$ & $8.51,14.9$ & $17.6,30.8$ & $22.3,39.1$ & 57.1 \\
EW, 7/11 BV days & $9.37,16.1$ & $11.5,19.8$ & $15.0,25.9$ & $22.2,38.2$ & 58.1 \\
\hline
\end{tabular}



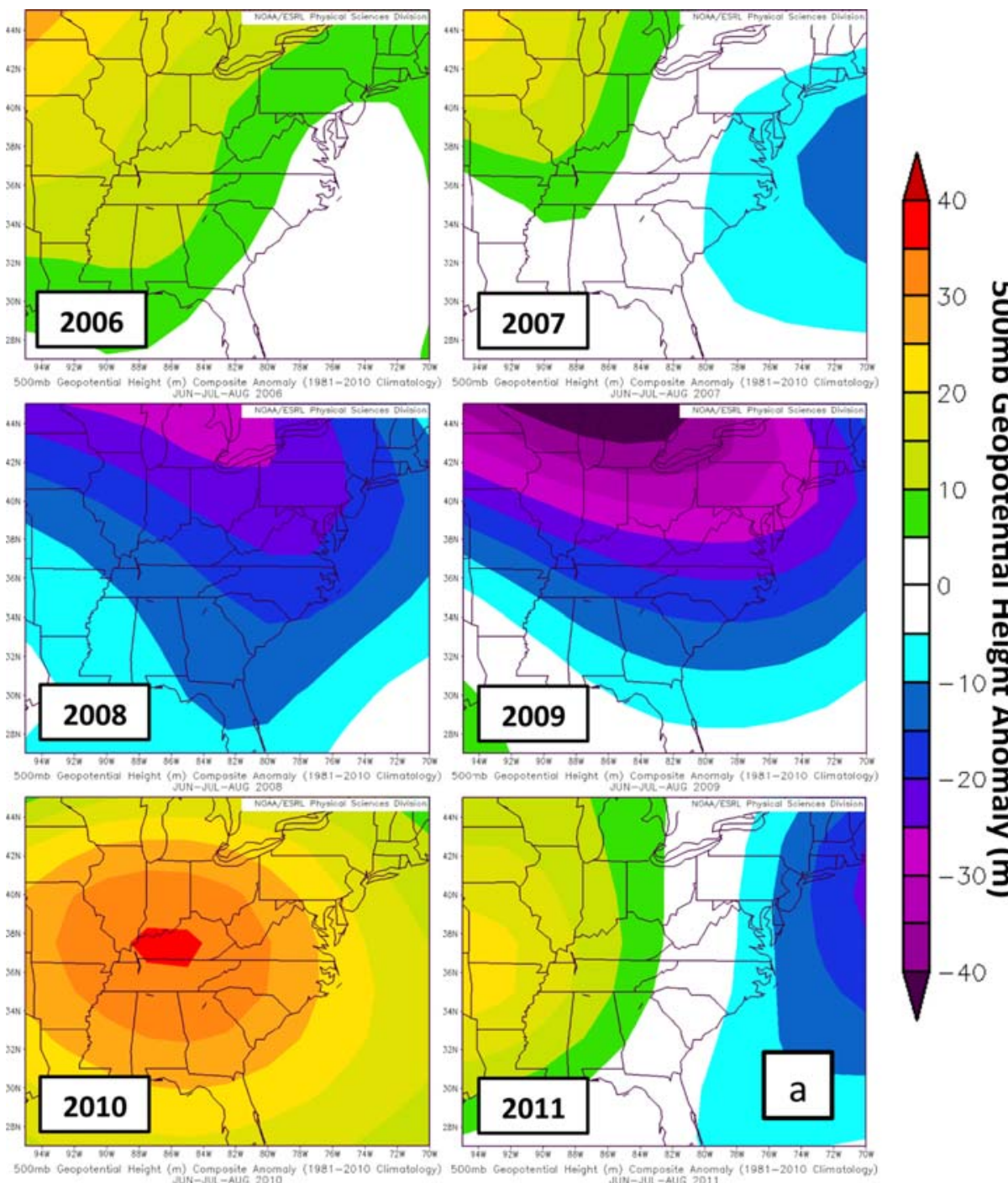

Fig. 12 Summary of meteorological variables to describe years 2006-2011 for the months JJA (Refer to Yorks et al. (2009) for statistics for 2004-2007). Data and graphical presentation from the Earth System Research laboratory (ESRL) of National Oceanic and Atmospheric Administration (NOAA). Anomalies relative to 1980 to 2011, for a $500 \mathrm{hPa}$ geopotential height; b Outgoing Long-wave Radiation (OLR), as a proxy for cloud cover; c seasonal surface temperature (warmer or cooler than normal)

layered, with ozone exceeding $100 \mathrm{ppbv}$ at $1.5-2 \mathrm{~km}, 6-8 \mathrm{~km}, 10-12 \mathrm{~km}$ and $13-16 \mathrm{~km}$; the EW sounding was broadly similar above $5 \mathrm{~km}$ (Fig. 10b). Over BV (Fig. 10a), RH was greater above $12 \mathrm{~km}$ than from 6 to $11 \mathrm{~km}$, where the RH was $<10 \%$. The moister upper troposphere suggests convective mixing whereas the drier region may have stratospheric origins, consistent with the RW character of the BV ozone profile (red shading in Fig. 10a). Indeed, below $1 \mathrm{~km}$ CO displays polluted values, 190-220 ppbv at BV (Fig. 10c) and 170 ppbv at EW (Fig. 10d), with 3-7 ppbv $\mathrm{NO}_{\mathrm{y}}$. Above $1 \mathrm{~km}$ the $\mathrm{EW}$ ozone declines to $60 \mathrm{ppbv}$, increasing again above $2.5 \mathrm{~km}$. At $1.5 \mathrm{~km}$ there is a local $110 \mathrm{ppbv}$ CO minimum (Fig. 10d). Above $1.5 \mathrm{~km}, \mathrm{CO}$ 

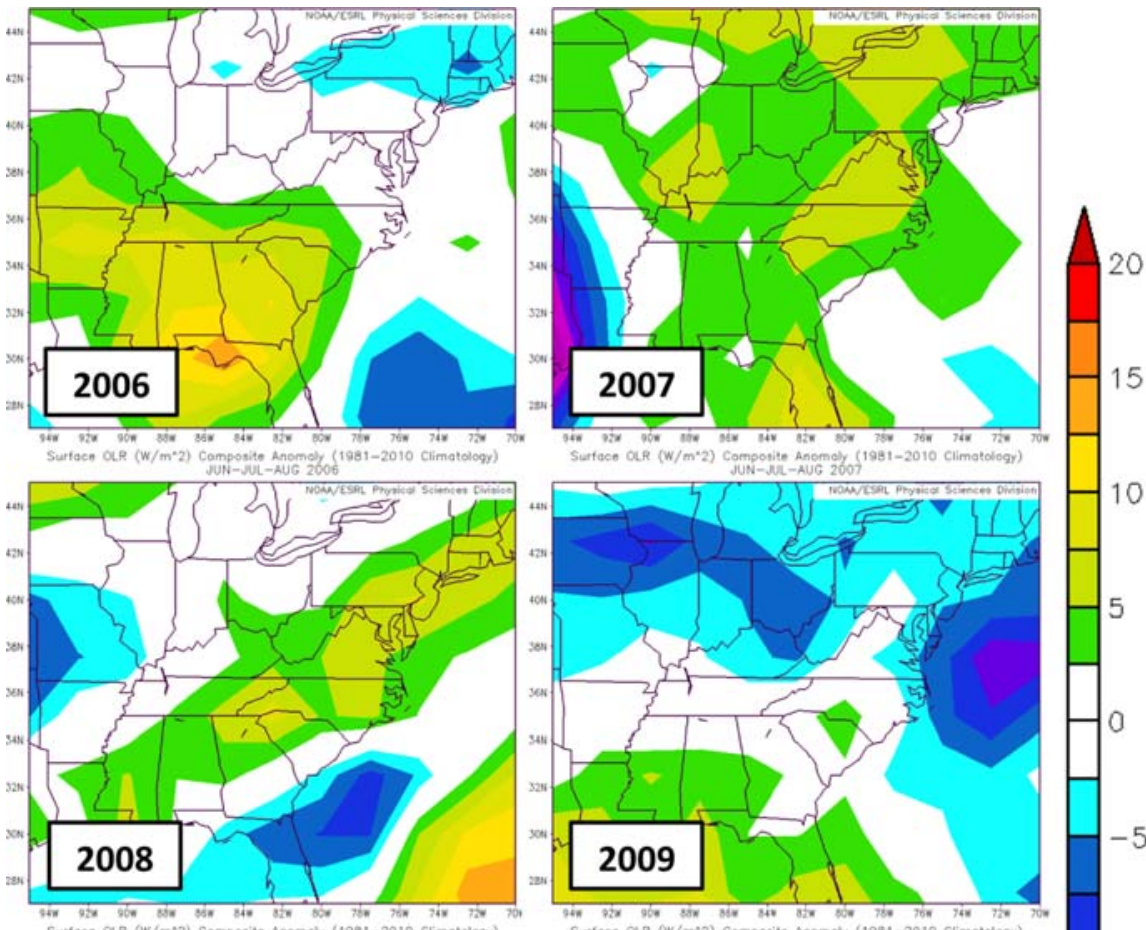

Surfoce OCR $\left(W / m^{2} 2\right)$ Composite Anomoly (1981-2010 Climatology)
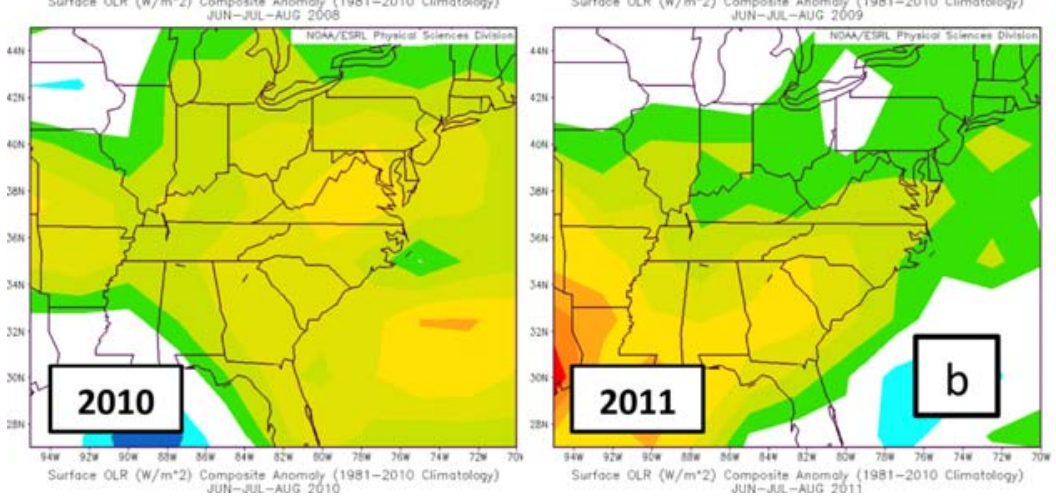

Fig. 12 (continued)

increases to $125 \mathrm{ppbv}$, then declines to $100 \mathrm{ppbv}$ at $3.5 \mathrm{~km}$. The near-surface concentration of $\mathrm{NO}_{\mathrm{y}}$ is $\sim 4$ ppbv, but declines above $1 \mathrm{~km}$.

Flights on 21 July were made by the P-3, UC-12 and UMD Cessna (He et al. 2014). There were two soundings each at BV and EW; the later profiles (1940-2050 UTC) are depicted in Fig. 10e, f. The 5th Code Orange day, with 8-h maximum 79 ppbv ozone (Table 2), is recorded at BV. Below $1 \mathrm{~km}$ during the earlier P-3 spiral over BV (not shown), the highest $\mathrm{NO}_{\mathrm{y}}(14$ ppbv) and CO (315 ppbv) concentrations of the DISCOVER-AQ P-3 flights were observed. In the second BV spiral, ozone (CO) is 80 (210) ppbv (Fig. 10g); the $\mathrm{NO}_{\mathrm{y}}$ concentrations are half the level of $4 \mathrm{~h}$ earlier. 

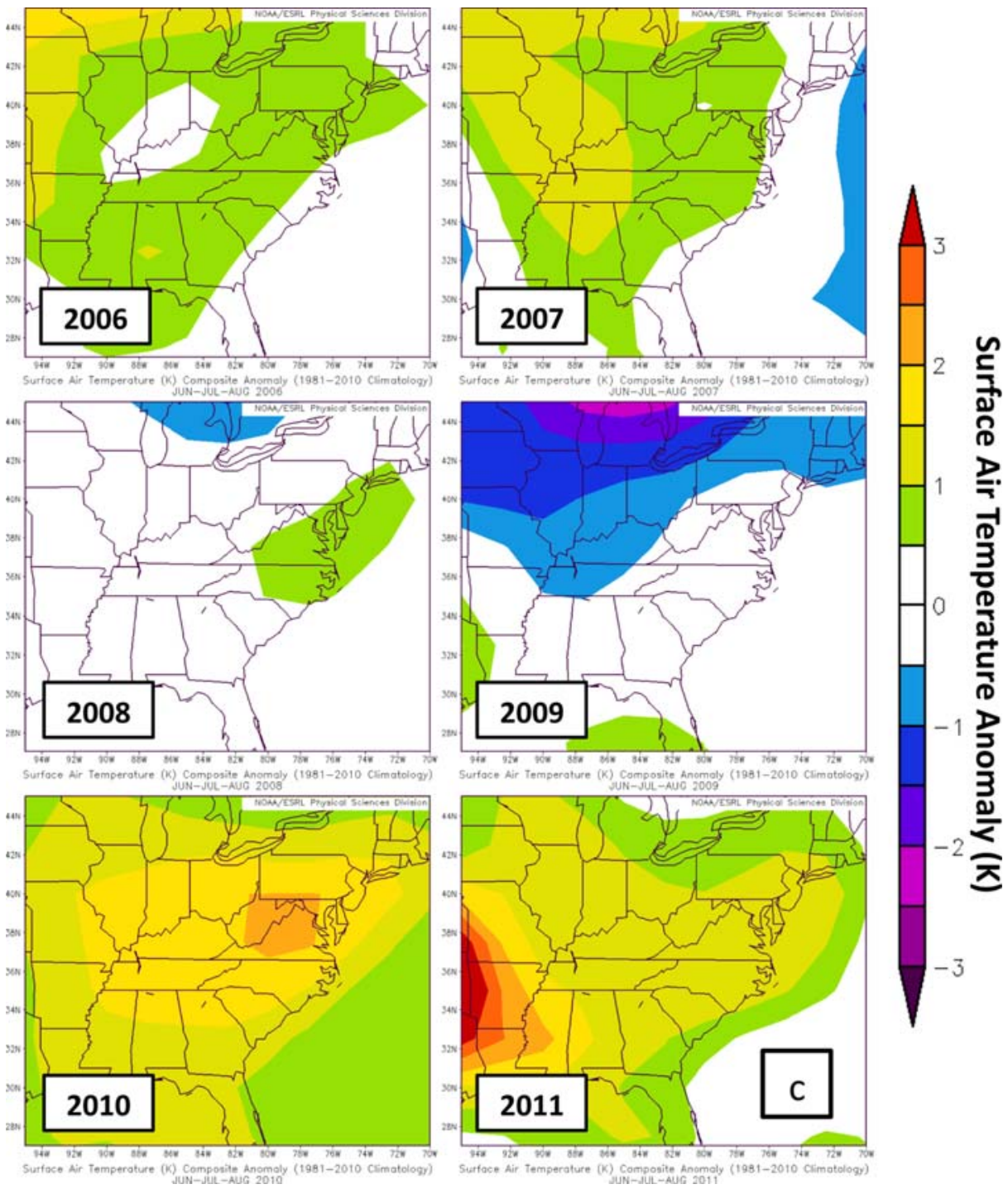

Fig. 12 (continued)

In all four 21 July soundings (two depicted in Fig. 10e, f), from 5 to $10 \mathrm{~km}$, ozone increased from the prior day to $100 \mathrm{ppbv}$ with dry conditions. Stratospheric influence is implicated; note a thin dry layer at the top of the BL (Fig. 10e, f). Stratospheric influence over EW is also suggested by $\mathrm{CO}$ and $\mathrm{NO}_{\mathrm{y}}$ drop-offs above $2 \mathrm{~km}$ (Fig. 10h). In the EW sounding (Fig. 10f), an extended GW signature (gray shading) implies recent mixing, but the BL is capped at $0.5 \mathrm{~km}$. A 100-plus ppbv ozone layer at 2050 UTC extends above the BL over EW but does not mix down to the surface. The EW 8-h maximum is $<75$ ppbv so EW remained within the Code Yellow range (Table 2).

On 22 July, there was only one BV launch (Fig. 10i). From the surface readings (Table 2; cf Fig. 10i, j) it is seen that EW and BV surface ozone is reversed from the day prior. BV (Fig. 10k) just missed Code Orange with a 74 ppbv 8-h mean. A situation 
described by Stauffer et al. (2012) as "interrupted bay breeze" allows EW ozone to build to 90-plus ppbv after a thunderstorm (second launch, Fig. 10j). The 8-h EW surface ozone maximum is $102 \mathrm{ppbv}$, giving the second July 2011 Code Red day at EW. Above $6 \mathrm{~km}$ in the EW sounding (Fig. 10j), a multi-layered high-ozone structure with low RH (Fig. 1d) remains intact for the third day. The P-3 spiral indicates low $\mathrm{CO}$ and $\mathrm{NO}_{\mathrm{y}}$ above $1.5 \mathrm{~km}$ over EW (Fig. 101). Despite the polluted conditions of the late afternoon sampling, the late morning soundings of 22 July (not shown) have a well-defined BL to $\sim 580 \mathrm{~m}$ within which ozone is $\sim 60$ ppbv, which is relatively clean air. The EW morning sampling on 22 July, with VOC unusually low in anthropogenic species and elevated in biogenics (Halliday et al. 2013), is traced back to rural western Maryland and Pennsylvania. Evidently, a wind shift following the thunderstorm (note vertical mixing signature in GW feature, gray shading in Fig. 10j) allowed the bay-breeze to introduce polluted air before it was interrupted.

\section{DISCOVER-AQ in the context of Beltsville ozone climatology (2006-2011)}

\subsection{Satellite comparison overview}

Ozone soundings have been taken at BV for the purpose of studying pollution since 2004 (Thompson et al. 2007a, b). Data from nighttime and early morning launches are not included in satellite comparisons (Fig. 2a) and budget calculations (Fig. 11). Figure 2a shows that for 2006-2011, there are 3-8 overpasses/year with average 3\% offsets. Like the 2011 OMI-sonde differences (Fig. 2), OMI total ozone is usually lower than the BV sondes.

\subsection{LID Interannual variability and meteorological indicators}

Figure 11 displays TTOC and LID ozone budgets for BV JJA soundings during 20062010. A summary of mean TTOC and LID budgets for BV (2006-2011) and EW (July 2011) appears in Table 5. A striking difference between the 2011 TTOC at BV and the prior 5 years is the magnitude of the DISCOVER-AQ TTOC. Although the average TTOC for 2010 and 2011 at BV is essentially the same (59 DU) and $<10 \%$ greater than the $2006-$ 2009 mean, the number of TTOC greater than 65 DU in 2011 is unique. Seven of 15 of the BV DISCOVER-AQ sondes (Fig. 6a) have TTOC > 65 DU whereas from 2006 to 2010 only 1 in 41 soundings was that high (Fig. 11). As stated above, 2009 was a low-ozone year at BV. Ozone in the BL (2009 entry, Table 5) is among the lowest in the 6-year BV record, with both GW and RW amounts relatively high. In Thompson et al. (2007a) it was shown that RW segments tend to be higher in years with lower surface pressure, ie with conditions that foster less photochemical ozone formation. We examine this further by looking at meteorological conditions for 2006-2011.

Parameters assembled from NCEP/NCAR reanalysis are used to examine large scale variability in the DISCOVER-AQ sampling region (Fig. 12; http://www.esrl.noaa.gov/ $\mathrm{psd} / \mathrm{data} /$ composites/hour/). The $500 \mathrm{mb}$ geopotential height anomalies from the 19812010 climatological average for JJA are well below normal in 2008 and 2009 (Fig. 12a). During the summer months of 2008 and 2009, a more active wave pattern led to lower $500 \mathrm{mb}$ heights (Fig. 12a) and increased stratospheric intrusions, causing enhanced RW signatures at Beltsville in 2008 (17.9 DU average) and 2009 (22.0 DU). The summers in 2006 (9.36 DU ozone, Table 5) and 2009 (9.74 DU) were rainier than normal; enhanced 
cloudiness, implied from out-going long-wave radiation (OLR) in 2009 (Fig. 12b), resulted in lower BL ozone due to suppressed ozone photochemical production. Warmer than average summers (Fig. 12c) in 2007, 2008, 2010 and 2011 (10.4-11.7 DU at BV) help to explain relatively enhanced BL ozone (Table 5, Fig. 11). Although only July 2011 is available for comparison between EW (8.66 DU in Table 4) and BV (11.3 DU), the July LFT and BL ozone at EW appear to be affected by the bay breeze that leads to lower BL heights (Fig. 1b; see Stauffer et al. (2012)). Thus, EW BL ozone is $20 \%$ lower than at BV (Table 5) despite the fact that EW surface ozone is usually higher (Table 2, Fig. 4). In Table 5 the second EW budget, based on days for which there were BV launches, shows similar RW and Residual ozone at the two sites but a higher GW fraction at EW, implying greater mixing in the free troposphere.

\section{Summary}

Using soundings, aircraft and ground based data from the July 2011 DISCOVER-AQ experiment, we investigated the variability of tropospheric ozone at two suburban locations in Maryland: Beltsville near Washington, DC and Edgewood near Baltimore. In addition, satellite measurements, based on OMI (total ozone) and OMI/MLS (tropospheric column) were compared to the total and partial ozone column measurements from the sondes. Total ozone at both sites (in the case of BV, also including summer soundings from 2006 to 2011) averaged $3 \%$ higher than OMI, not statistically significant. At both locations in July 2011, tropospheric column ozone from the sonde (surface to $200 \mathrm{hPa}$ ) was $10 \%$ greater than the corresponding OMI/MLS TTOR product, which is significant. The latter discrepancy is not consistently due to undetected high ozone amounts in the BL (Stauffer et al. 2012; Martins et al. 2013). The DISCOVER-AQ TTOR evaluation is similar to July comparisons for Wallops Island (2005-2010, Normile et al. 2014, in review), although TTOR-sonde offsets are more variable at Wallops.

Laminar analysis of tropospheric ozone column segments that are influenced by convective and advective transport reveal differences in BV and EW. Vertical mixing in the free troposphere was stronger at EW, denoted by the LID Gravity Wave designation (Thompson et al. 2007a), for days when both stations launched ozonesondes and aircraft profiled overhead. Vertical mixing was a persistent signal in EW sondes even though a capped BL over EW implies some decoupling of the BL and LFT (Martins et al. 2013). Approximately half the ozone soundings in the LFT over BV and EW were very dry (RH $<20 \%$ ) with low-concentration $\mathrm{NO}_{\mathrm{y}}$ and $\mathrm{CO}$ layers measured by the P-3, suggesting stratospheric influence.

Throughout July 2011, the P-3 ozone, CO and $\mathrm{NO}_{\mathrm{y}}$ profiles over BV and EW were broadly similar but detailed laminae differed, with higher $\mathrm{CO}$ and $\mathrm{NO}_{\mathrm{y}}$ below $2 \mathrm{~km}$ (maximum altitude for P-3 sampling over BV) alternating between the two sites. Differences for $\mathrm{CO}$ were usually 20-30 ppbv in the BL but $\mathrm{NO}_{\mathrm{y}}$ sometimes differed by $50 \%$ (3-4 ppbv). Surface 8 -h maxima ozone at the two sites disagreed by 5-25 ppbv on 23 of 31 days, with EW higher on 16 days and BV higher on 7 days. Interannual variability of the tropospheric column LID budgets at BV (2006-2011) is consistent with meteorological patterns. Assuming that RW denotes stratospheric influence, the $25 \%$ of tropospheric ozone column designated as RW over BV and EW in July 2011 appears to be typical for warm, high-pressure conditions in the mid-Atlantic (Thompson et al. 2007b). 
Acknowledgments We are grateful to the DISCOVER-AQ leadership (J. H. Crawford, PI; K. E. Pickering, Project Scientist; M. M. Kleb, Deputy) for overall design, planning and execution of the Maryland phase of the project. A number of people provided additional support and scientific insights for Beltsville (R. Sakai, M. Payne, J. Fuentes) and the NATIVE site at Edgewood (H. Halliday, N. Abuhassan, J. Herman, T. Berkoff, R. Delgado, P. Decola, D. M. Giles, the Leosphere group). R. R. Dickerson (Univ. Maryland), W. F. Ryan (PSU) and the folks at MDE provided invaluable perspective on pollution in the Baltimore-Edgewood area. Penn State's participation in DISCOVER-AQ is sponsored by NASA Grant NNG10AJ38. Additional support for data collection and analysis was provided by NASA's Tropospheric Chemistry Program (Grants NNG06GB18G and NNX08AJ15G), Howard University BCCSO (NNX10Q11A) and AQAST (Air Quality Applied Sciences Team, Grant NNX11AQ44G). J. A Bielli and J. M. Festa (PSU) carried out some of the early analyses.

Open Access This article is distributed under the terms of the Creative Commons Attribution License which permits any use, distribution, and reproduction in any medium, provided the original author(s) and the source are credited.

\section{References}

Browell, E.V., Fenn, M.A., Butler, C.F., Grant, W.B., Merrill, J.T., Newell, R.E., Bradshaw, J.D., Sandholm, S.T., Anderson, B.E., Bandy, A.R., Bachmeier, A.S., Blake, D.R., Davis, D.D., Gregory, G.L., Heikes, B.G., Kondo, Y., Liu, S.C., Rowland, F.S., Sachse, G.W., Singh, H.B., Talbot, R.W., Thornton, D.C.: Large-scale air mass characteristics observed over Western Pacific during summertime. J. Geophys. Res. 101(D1), 16911712 (1996). doi:10.1029/95JD02200

Chatfield, R.B., Esswein, R.F.: Estimation of surface O3 from lower-troposphere partial-column information: vertical correlations and covariances in ozonesonde profiles. Atmos. Environ. 61, 103-113 (2012). doi:10. 1016/j.atmosenv.2012.06.033

Cooper, O.R., Oltmans, S.J., Johnson, B.J., Brioude, J., Angevine, W., Trainer, M., Parrish, D.D., Ryerson, T.R., Pollack, I., Cullis, P.D., Ives, M.A., Tarasick, D.W., Al-Saadi, J., Stajner, I.: Measurement of western US baseline ozone from the surface to the tropopause and assessment of downwind impact regions. J. Geophys. Res.-Atmos. 116(D00V03), 1-22 (2011). doi:10.1029/2011jd016095

Deshler, T., Mercer, J.L., Smit, H.G.J., Stubi, R., Levrat, G., Johnson, B.J., Oltmans, S.J., Kivi, R., Thompson, A.M., Witte, J., Davies, J., Schmidlin, F.J., Brothers, G., Sasaki, T.: Atmospheric comparison of electrochemical cell ozonesondes from different manufacturers, and with different cathode solution strengths: the balloon experiment on standards for ozonesondes. J. Geophys. Res.-Atmos. 113(D4), D04307 (2008). doi: 10.1029/2007jd008975

Doughty, D.C., Thompson, A.M., Schoeberl, M.R., Stajner, I., Wargan, K., Hui, W.C.J.: An intercomparison of tropospheric ozone retrievals derived from two Aura instruments and measurements in western North America in 2006. J. Geophys. Res. Atmos. 116(D6), 11 (2011). doi:10.1029/2010jd014703

Doughty, D.C., Fuentes, J.D., Sakai, R., Hu, X.-M., Sanchez, K.: Nocturnal isoprene declines in a semi-urban environment. J. Atmos. Chem. (2012). doi:10.1007/s10874-012-9247-0

Fenn, M.A., Browell, E.V., Butler, C.F., Grant, W.B., Kooi, S.A., Clayton, M.B., Gregory, G.L., Newell, R.E., Zhu, Y., Dibb, J.E.: Ozone and aerosol distributions and air mass characteristics over the South Pacific during the burning season. J. Geophys. Res. 104(D13), 16197-16212 (1999). doi:10.1029/1999JD900065

Hains, J.C., Taubman, B.F., Thompson, A.M., Stehr, J.W., Marufu, L.T., Doddridge, B.G., Dickerson, R.R.: Origins of chemical pollution derived from Mid-Atlantic aircraft profiles using a clustering technique. Atmos. Environ. 42(8), 1727-1741 (2008). doi:10.1016/j.atmosenv.2007.11.052

Halliday, H.S., Thompson, A.M., Martins, D.K., Kollonige, D.W., Fuentes, J.D.: Behavior of volatile organic compounds sampled in the Baltimore/DC Region during July 2011 for DISCOVER-AQ. J. Atmos. Chem. Submitted (2013)

He, H., Loughner, C. P., Stehr, J. W., Arkinson, H. L. Brent, L. C., Follette-Cook, M. B., Tzortziou, M. A. Pickering, K. E., Thompson, A. M., Martins, D. K., Diskin, G. S., Anderson, B. E., Crawford, J. H., Weinheimer, A. J., Lee, P., Hains, J. C., Dickerson, R. R.: An elevated reservoir of air pollutants over the Mid-Atlantic States during the 2011 DISCOVER-AQ campaign: Airborne measurements and numerical simulations. Atmos. Environ. 85, 18-30 (2014)

Heffter, J.L.: Air resources laboratories atmospheric transport and dispersion model, NOAA Tech. Memo., ERL ARL-81, pp. 24 (1980) 
Johnson, B.J., Oltmans, S.J., Vömel, H., Smit, H.G.J., Deshler, T., Kröger, C.: Electrochemical concentration cell (ECC) ozonesonde pump efficiency measurements and tests on the sensitivity to ozone of buffered and unbuffered ECC sensor cathode solutions. J. Geophys. Res. 107(D19), 4393 (2002). doi:10.1029/ 2001JD000557

Luzik, A.M.: Quantifying forest fire enhancement of the free tropospheric ozone column during the IONS-04, IONS-06, and ARC-IONS campaigns. http://etda.libraries.psu.edu/theses/approved/WorldWideIndex/ETD3889/index.html (2009)

Martins, D.K., Stauffer, R.M., Thompson, A.M., Knepp, T.N., Pippin, M.: Surface ozone at a coastal suburban site in 2009 and 2010: relationships to chemical and meteorological processes. J. Geophys. Res. 117(D5), D05306 (2012). doi:10.1029/2011JD016828

Martins, D.K., Stauffer, R.M., Thompson, A.M., Halliday, H.S., Kollonige, D.W., Joseph, E., Weinheimer, A.J.: Ozone correlations between upper air partial columns and the near-surface. J. Atmos. Chem. (2013). doi:10. 1007/s10874-013-9259-4

McPeters, R.D., Labow, G.J.: Climatology 2011: an MLS and sonde derived ozone climatology for satellite retrieval algorithms. J. Geophys. Res.-Atmos. 117, D10303 (2012). doi:10.1029/2011jd017006

Morris, G.A., Hersey, S., Thompson, A.M., Pawson, S., Nielsen, J.E., Colarco, P.R., McMillan, W.W., Stohl, A., Turquety, S., Warner, J., Johnson, B.J., Kucsera, T.L., Larko, D.E., Oltmans, S.J., Witte, J.C.: Alaskan and Canadian forest fires exacerbate ozone pollution over Houston, Texas, on 19 and 20 July 2004. J. Geophys. Res.-Atmos. 111(D24), D24S03 (2006). doi:10.1029/2006jd007090

Morris, V., Yu, T.-W., Joseph, E., Armstrong, R., Fitzgerald, R., Karim, R., Liang, X.-Z., Min, Q.: The NOAA Center for Atmospheric Sciences (NCAS). Bull. Am. Meteorol. Soc. 88(2), 141-144 (2007). doi:10.1175/ BAMS-88-2-141

Morris, G.A., Ford, B., Rappenglück, B., Thompson, A.M., Mefferd, A., Ngan, F., Lefer, B.: An evaluation of the interaction of morning residual layer and afternoon mixed layer ozone in Houston using ozonesonde data. Atmos. Environ. 44(33), $4024-4034$ (2010). doi:10.1016/j.atmosenv.2009.06.057

Newchurch, M., Ayoub, M., Oltmans, S., Johnson, B., Schmidlin, F.: Vertical distribution of ozone at four sites in the United States. J. Geophys. Res. 108(D1), 4031 (2003). doi:10.1029/2002JD002059

Rappenglueck, B., Perna, R., Zhong, S., Morris, G.A.: An analysis of the vertical structure of the atmosphere and the upper-level meteorology and their impact on surface ozone levels in Houston, Texas. J. Geophys. Res.Atmos. 113(D17), D17315 (2008). doi:10.1029/2007jd009745

Reed, A.J., Thompson, A.M., Kollonige, D.W., Martins, D.K., Tzortziou, M.A., Herman, J.R., Berkoff, T.A., Abuhassan, N.K., Cede, A.: Effects of local meteorology and chemistry on ozone and nitrogen dioxide retrievals: OMI and Pandora spectrometers during DISCOVER-AQ. J. Atmos. Chem. (2013). doi:10.1007/s10874-013-9254-9

Sachse, G.W., Hill, G.F., Wade, L.O., Perry, M.G.: Fast-response, high-precision carbon monoxide sensor using a tunable diode-laser absorption technique. J. Geophys. Res.-Atmos. 92(D2), 2071-2081 (1987). doi:10.1029/ JD092iD02p02071

Schoeberl, M.R., Ziemke, J.R., Bojkov, B., Livesey, N., Duncan, B., Strahan, S., Froidevaux, L., Kulawik, S., Bhartia, P.K., Chandra, S., Levelt, P.F., Witte, J.C., Thompson, A.M., Cuevas, E., Redondas, A., Tarasick, D.W., Davies, J., Bodeker, G., Hansen, G., Johnson, B.J., Oltmans, S.J., Vomel, H., Allaart, M., Kelder, H., Newchurch, M., Godin-Beekmann, S., Ancellet, G., Claude, H., Andersen, S.B., Kyro, E., Parrondos, M., Yela, M., Zablocki, G., Moore, D., Dier, H., von der Gathen, P., Viatte, P., Stubi, R., Calpini, B., Skrivankova, P., Dorokhov, V., de Backer, H., Schmidlin, F.J., Coetzee, G., Fujiwara, M., Thouret, V., Posny, F., Morris, G., Merrill, J., Leong, C.P., Koenig-Langlo, G., Joseph, E.: A trajectory-based estimate of the tropospheric ozone column using the residual method. J. Geophys. Res.-Atmos. 112(D24), D24S49 (2007). doi:10.1029/2007jd008773

Singh, H., Brune, W., Crawford, J., Jacob, D.J., Russel, P.: Overview of the summer 2004 intercontinental chemical transport experiment-North America (INTEX-A). J. Geophys. Res. 111, D24S01 (2006). doi:10. 1029/2006JD007905

Smit, H.G.J., Straeter, W., Johnson, B.J., Oltmans, S.J., Davies, J., Tarasick, D.W., Hoegger, B., Stubi, R., Schmidlin, F.J., Northam, T., Thompson, A.M., Witte, J.C., Boyd, I., Posny, F.: Assessment of the performance of ECC-ozonesondes under quasi-flight conditions in the environmental simulation chamber: Insights from the Juelich Ozone Sonde Intercomparison Experiment (JOSIE). J. Geophys. Res.-Atmos. 112(D19), D19306 (2007). doi:10.1029/2006jd007308

Smit, H.G.J. et al.: Quality assurance and quality control for ozonesonde measurements in GAW. GAW Report No. 201. (2011)

Stauffer, R.M., Thompson, A.M., Martins, D.K., Clark, R.D., Goldberg, D.L., Loughner, C.P., Delgado, R., Dickerson, R.R., Stehr, J.W., Tzortziou, M.A.: Bay breeze influence on surface ozone at Edgewood, MD during July 2011. J. Atmos. Chem., 1-19. doi:10.1007/s10874-012-9241-6 (2012)

Taubman, B.F., Hains, J.C., Thompson, A.M., Marufu, L.T., Doddridge, B.G., Stehr, J.W., Piety, C.A., Dickerson, R.R.: Aircraft vertical profiles of trace gas and aerosol pollution over the mid-Atlantic United 
States: statistics and meteorological cluster analysis. J. Geophys. Res. Atmos. 111(D10), D10S07 (2006). doi:10.1029/2005jd006196

Teitelbaum, H., Ovarlez, J., Kelder, H., Lott, F.: Some observations of gravity-wave-induced structure in ozone and water vapour during EASOE. Geophys. Res. Lett. 21(13), 1483-1486 (1994). doi:10.1029/93GL02434

Thompson, A.M., Doddridge, B.G., Witte, J.C., Hudson, R.D., Luke, W.T., Johnson, J.E., Johnson, B.J., Oltmans, S.J., Weller, R.: A tropical Atlantic paradox: shipboard and satellite views of a tropospheric ozone maximum and wave-one in January-February 1999. Geophys. Res. Lett. 27(20), 3317-3320 (2000). doi:10. 1029/1999GL011273

Thompson, A.M., Stone, J.B., Witte, J.C., Miller, S.K., Pierce, R.B., Chatfield, R.B., Oltmans, S.J., Cooper, O.R., Loucks, A.L., Taubman, B.F., Johnson, B.J., Joseph, E., Kucsera, T.L., Merrill, J.T., Morris, G.A., Hersey, S., Forbes, G., Newchurch, M.J., Schmidlin, F.J., Tarasick, D.W., Thouret, V., Cammas, J.P.: Intercontinental Chemical Transport Experiment Ozonesonde Network Study (IONS) 2004: 1. Summertime upper troposphere/lower stratosphere ozone over northeastern North America. J. Geophys. Res.-Atmos. 112(D12), D12S13 (2007a). doi:10.1029/2006jd007441

Thompson, A.M., Stone, J.B., Witte, J.C., Miller, S.K., Oltmans, S.J., Kucsera, T.L., Ross, K.L., Pickering, K.E., Merrill, J.T., Forbes, G., Tarasick, D.W., Joseph, E., Schmidlin, F.J., McMillan, W.W., Warner, J., Hintsa, E.J., Johnson, J.E.: Intercontinental Chemical Transport Experiment Ozonesonde Network Study (IONS) 2004: 2. Tropospheric ozone budgets and variability over northeastern North America. J. Geophys. Res.Atmos. 112, D12S13 (2007b). doi:10.1029/2006jd007670

Thompson, A.M., Witte, J.C., Smit, H.G.J., Oltmans, S.J., Johnson, B.J., Kirchhoff, V., Schmidlin, F.J.: Southern Hemisphere Additional Ozonesondes (SHADOZ) 1998-2004 tropical ozone climatology: 3. Instrumentation, station-to-station variability, and evaluation with simulated flight profiles. J. Geophys. Res.-Atmos. 112(D3), D03304 (2007c). doi:10.1029/2005jd007042

Thompson, A.M., MacFarlane, A.M., Morris, G.A., Yorks, J.E., Miller, S.K., Taubman, B.F., Verver, G., Voemel, H., Avery, M.A., Hair, J.W., Diskin, G.S., Browell, E.V., Valverde Canossa, J., Kucsera, T.L., Klich, C.A., Hlavka, D.L.: Convective and wave signatures in ozone profiles over the equatorial Americas: views from TC4 2007 and SHADOZ. J. Geophys. Res.-Atmos. 115, D00J23 (2010). doi:10.1029/2009jd012909

Thompson, A.M., Oltmans, S.J., Tarasick, D.W., von der Gathen, P., Smit, H.G.J., Witte, J.C.: Strategic ozone sounding networks: review of design and accomplishments. Atmos. Environ. 45(13), 2145-2163 (2011). doi:10.1016/j.atmosenv.2010.05.002

Thompson, A.M., Miller, S.K., Tilmes, S., Kollonige, D.W., Witte, J.C., Oltmans, S.J., Johnson, B.J., Fujiwara, M., Schmidlin, F.J., Coetzee, G.J.R., Komala, N., Maata, M., Mohamad, M.B., Nguyo, J., Mutai, C., Ogino, S.Y., Da Silva, F.R., Paes Leme, N.M., Posny, F., Scheele, R., Selkirk, H.B., Shiotani, M., Stuebi, R., Levrat, G., Calpini, B., Thouret, V., Tsuruta, H., Valverde Canossa, J., Voemel, H., Yonemura, S., Andres Diaz, J., Thanh, N.T.T., Ha, H.T.T.: Southern Hemisphere Additional Ozonesondes (SHADOZ) ozone climatology (2005-2009): Tropospheric and tropical tropopause layer (TTL) profiles with comparisons to OMI-based ozone products. J. Geophys. Res.-Atmos. 117, D2330 (2012). doi:10.1029/2011jd016911

Yorks, J.E., Thompson, A.M., Joseph, E., Miller, S.K.: The variability of free tropospheric ozone over Beltsville, Maryland (39N, 77W) in the summers 2004-2007. Atmos. Environ. 43(11), 1827-1838 (2009). doi:10. 1016/j.atmosenv.2008.12.049 